\title{
Carbon Catabolite Repression in Filamentous Fungi
}

\author{
Muhammad Adnan ${ }^{1,2}$, Wenhui Zheng ${ }^{1,2}$, Waqar Islam ${ }^{1}$, Muhammad Arif ${ }^{1}$, \\ Yakubu Saddeeq Abubakar 1,2 (D), Zonghua Wang ${ }^{1,2}$ and Guodong Lu 1,2,* (D) \\ 1 State Key Laboratory of Ecological Pest Control for Fujian and Taiwan Crops, Fujian Agriculture and \\ Forestry University, Fuzhou 350002, China; 2151904006@m.fafu.edu.cn (M.A.); wenhuiz@fafu.edu.cn (W.Z.);

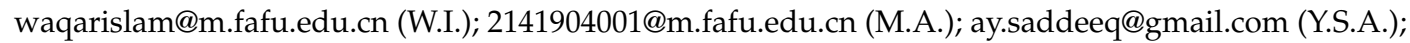 \\ wangzh@fafu.edu.cn (Z.W.) \\ 2 Key Laboratory of Bio-Pesticides and Chemical Biology, Ministry of Education, Fujian Agriculture and \\ Forestry University, Fuzhou 350002, China \\ * Corresponding author: lgd@fafu.edu.cn; Tel.: +86-591-8378-9478
}

Received: 18 November 2017; Accepted: 20 December 2017; Published: 24 December 2017

\begin{abstract}
Carbon Catabolite Repression (CCR) has fascinated scientists and researchers around the globe for the past few decades. This important mechanism allows preferential utilization of an energy-efficient and readily available carbon source over relatively less easily accessible carbon sources. This mechanism helps microorganisms to obtain maximum amount of glucose in order to keep pace with their metabolism. Microorganisms assimilate glucose and highly favorable sugars before switching to less-favored sources of carbon such as organic acids and alcohols. In CCR of filamentous fungi, CreA acts as a transcription factor, which is regulated to some extent by ubiquitination. CreD-HulA ubiquitination ligase complex helps in CreA ubiquitination, while CreB-CreC deubiquitination (DUB) complex removes ubiquitin from CreA, which causes its activation. CCR of fungi also involves some very crucial elements such as Hexokinases, cAMP, Protein Kinase (PKA), Ras proteins, G protein-coupled receptor (GPCR), Adenylate cyclase, RcoA and SnfA. Thorough study of molecular mechanism of CCR is important for understanding growth, conidiation, virulence and survival of filamentous fungi. This review is a comprehensive revision of the regulation of CCR in filamentous fungi as well as an updated summary of key regulators, regulation of different CCR-dependent mechanisms and its impact on various physical characteristics of filamentous fungi.
\end{abstract}

Keywords: carbon catabolite repression; sensing and signaling pathway; phosphorylation; hexokinase; transport proteins; cAMP; $C r e A$; ubiquitination

\section{Introduction}

Fungi are responsible for causing devastating diseases of fauna and flora. Pathogenic fungi have developed genetic mechanisms and molecular strategies to survive unpredictable scenarios and establish effective disease conditions in their hosts [1-3]. Regulation of carbon metabolism is very important for disease establishment by filamentous fungi. Carbon Catabolite Repression helps microorganisms to precisely adapt their physiology to the environment. The importance of this fine tuning is illustrated by the finding that within populations there may be balancing selections for individuals with fast and slow rates of reprogramming [2,4,5]. CCR switches off certain enzymes required to utilize less-favored carbon sources when a more readily available carbon source is present in the medium $[1,5]$. Therefore, CCR acts as an economical instrument in microorganisms for screening glucose. Apart from regulating the uptake of glucose, CCR may also influence the survival of microorganisms by affecting virulence, adaptation, cellular communication and motility.

CCR has been studied extensively in Saccharomyces cerevisiae, which serves as a model organism for understanding the complexity of repression, derepression and induction of gene expression in 
response to glucose [2,6]. Among filamentous fungi, CCR has been studied most extensively in the model organism Aspergillus nidulans, which serves as a second model organism for comparison [7]. Mutants of CCR in $A$. nidulans have been mapped to define the genes $\mathrm{CreA}$ (Cre $=$ catabolite responsive elements), $\mathrm{CreB}, \mathrm{CreC}$ and $\mathrm{CreD}$ [8-11]. In addition, other species of Aspergillus such as A. oryzae and $A$. flavus have also been adequately studied in relation to CCR $[12,13]$.

CreA is a transcription factor, and like Mig1 in S. cerevisiae it has a $\mathrm{C}_{2} \mathrm{H}_{2}$ Zinc finger DNA binding domain required for CCR [5]. When glucose is detected by $A$. nidulans, CreA represses the genes that encode the enzymes that utilize other secondary carbon sources such as lignocellulose $[1,5,14]$. It is already known that $C r e A$ repression occurs at transcriptional level; however, this aspect needs further work $[5,15]$. The regulation of cellular activities is dependent on CCR under normal circumstances, which is further regulated by $\mathrm{Cre} A$ and its counterparts and also involves ubiquitination and phosphorylation. Addition and removal of ubiquitin molecules help in the activation of CreA. Moreover, CreB-CreC deubiquitination complex is also involved at this juncture [5]. Interaction of DUB enzymes with ubiquitin ligases and their combination control the quantity of transcription factors in CCR [16]. Similarly, phosphorylation controls the localization and function of CreA, by post-transcriptional modification [5]. Although CreA and MIG1 appear to be orthologs, there are obvious differences in the pathways governing CCR, as such pathways have diverged over evolutionary time. An understanding of the events in the divergence of such a complex regulatory network as CCR will provide an insight into the evolutionary mechanisms that allow rewiring of interconnected regulatory networks. In order to develop biotechnological processes, particularly for plant biomass deconstruction for conversion to high-value products, a more complete understanding of CCR in a wide variety of fungal species is needed [17-19].

\section{Sensing and Signaling Pathways of Carbon Catabolite Repression}

\subsection{Yeast}

The yeast, S. cerevisiae, has served as a model organism regarding CCR sensing and signaling cascades [20]. There are three main sensing and signaling pathways, which are interconnected and responsible for regulation of glucose metabolism in yeast [21]. The primary signal for triggering regulatory process is glucose itself [2,22]. Environmental signals are sensed by the $G$ protein-coupled receptors (GPCRs) or other unknown proteins, leading to the regulation of downstream pathways. The glucose-signaling pathways are cAMP/PKA (consisting of Ras and the model Gpr1/Gpa2), Rgt2/Snf3-Rgt1 and the main repressor pathway Mig1-Hxk2 involving Snf1 [2,23-26].

Activation of heterotrimeric and Ras proteins results in modulation of cAMP (cyclic adenosine monophosphate) levels upon a shift from low to high glucose. Although it is unclear how the G protein-coupled receptor (GPCR), Gpr1, senses glucose, the G $\alpha$ homolog, Gpa2, interacts with adenylate cyclase. Adenylate cyclase is more strongly controlled by Ras protein, which is further regulated by cdc 25 and Ira proteins (the controlling elements of adenylate cyclase) (Figure 1) [27,28]. This pathway operates under environmental conditions where PKA activation neither involves adenylate cyclase nor cAMP, but includes the G $\beta$-like proteins krh1, krh2 proteins and Sch9 protein kinase [29-31]. Therefore, in this pathway, Gpr1 and Gpa2 will activate PKA through krh1, krh2 and Sch9 proteins in a cAMP independent way (Figure 1). 


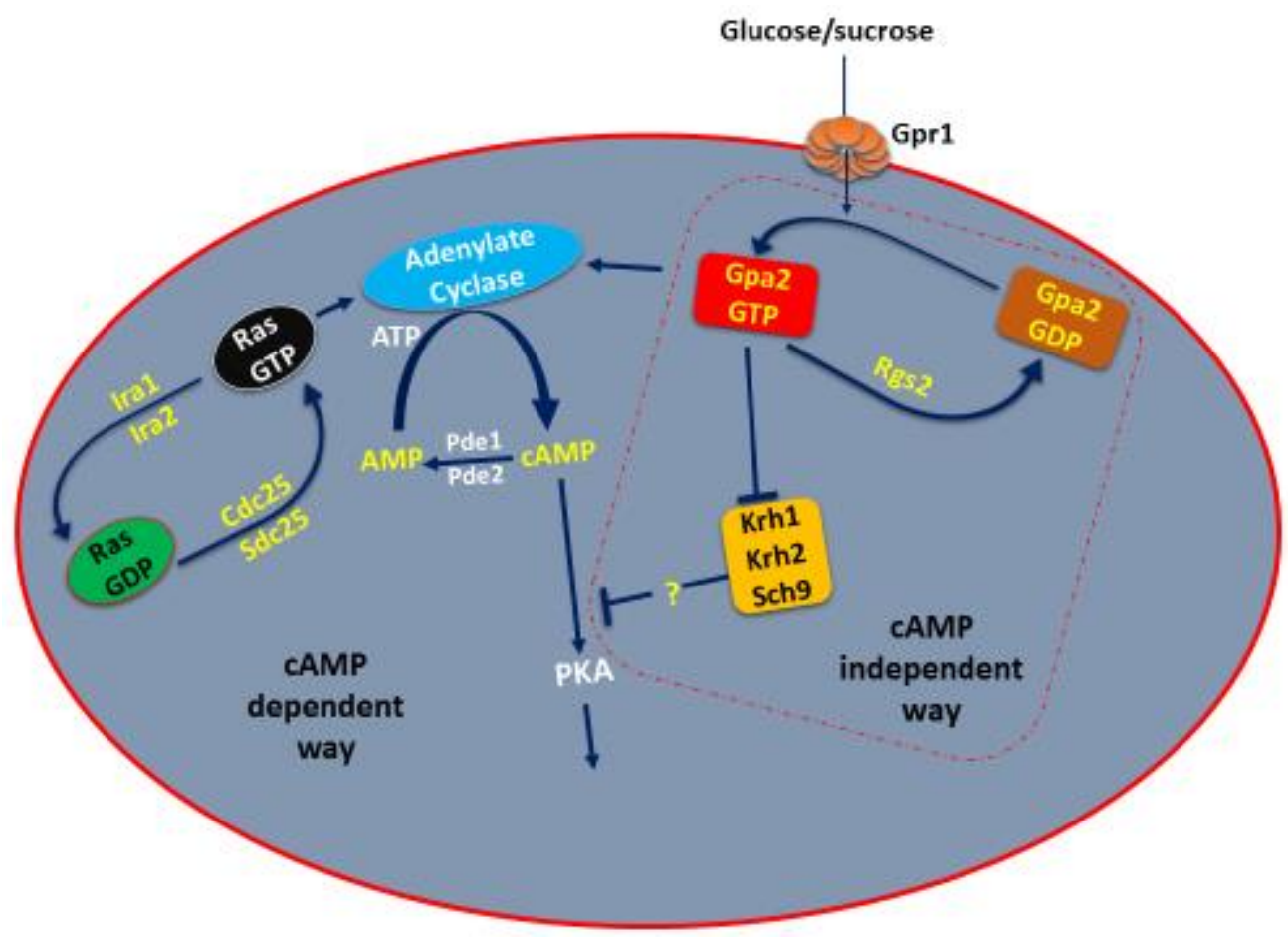

Figure 1. The PKA/Ras-cAMP Pathway in yeast. Adenylate cyclase is controlled by two G-Protein Systems in yeast. Ras1 and Ras2 need Sdc25 and cdc25 for activation. Ras Proteins are inactivated (Green) by Ira1 and Ira2. GPR1 system includes sucrose and glucose sensors Gpa2 and GPR1, which stimulate the adenylate activity. Krh1, Krh2, and Sch9 interact with the active Gpa2 (red), and seems to inhibit PKA activity by an unknown mechanism. Pde1 and Pde2 regulate cAMP concentration.

Entrance of glucose into the yeast cells is achieved by facilitated diffusion through hexose transporters (including HXT1-HXT17, GAL2, SNF3 and RGT2). The uptake of glucose from the environment is efficiently coordinated through the action of transporters of differing affinities. The activity of the transcriptional repressor (Rgt1) is controlled by the glucose sensors Snf3 and Rgt2. Rgt2 (low-affinity glucose sensor) senses high concentrations of glucose and is induced when glucose level is high within the medium, while Snf3 is a high-affinity glucose sensor and capable of inducing high-affinity transporters when the level of glucose is very low [32]. Rgt1 is a repressor of HXT genes in response to Snf3 and Rgt2 signaling. Moreover, different levels of PKA will affect phosphorylation of Rgt1 and influence its binding and blocking of HXT promoters [33-35]. Consequently, high glucose levels will cause complete activation and increased level of PKA, which leads to phosphorylation of Rgt1, therefore low affinity HXTs (HXT1, HXT3) will be induced [36]. On the other hand, low levels of glucose lead to weak activation of PKA and in this case only high affinity HXTs (HXT2, HXT4) can be induced [37].

Phosphorylated glucose can cause repression of many genes that are involved in alternate carbon source utilization e.g., gluconeogenesis and respiration through CCR. This mechanism involves transcriptional repression in the presence of glucose and relieves repression upon limited glucose levels. The signal required for glucose repression is phosphorylated glucose and hexokinases cause this phosphorylation. Yeasts possess three hexokinases Glk2, Hxk1, Hxk2, which can phosphorylate glucose (Table 1) [21,38]. In S. cerevisiae, the presence of only one of these enzymes is required for growth on glucose [21]. However, only Hxk2 acts in glucose sensing and can interact with the Mig1 repressor complex [34].

The major components of CCR in yeast are Glc7 (protein phosphatase), Snf1 protein kinase complex and Mig1 transcriptional repressor complex as shown in Figure $2[24,26,39]$. The DNA binding protein Mig1 forms a complex with the co-repressor proteins Tup1 and Ssn6 (Figure 2) in order 
to carry out repression of diverse gene families and related transcriptional regulators, such as MalR (maltose utilization), Gal4 (galactose utilization), Cat8 (gluconeogenic genes), and Hap4 (respiratory genes). Glucose-regulated subcellular localization of Mig1 is very important for its proper function in repression. Mig1 quickly moves to the nucleus in repressing glucose levels, and binds to the promoters of glucose repressible genes [22,40]. However, under glucose starvation, Mig1 is mobilized back to the cytoplasm due to phosphorylation by Snf1 [40].

Snf1, is the central element of signaling for glucose repression. The Snf1 kinase complex, during glucose-limiting conditions reprograms the transcription of metabolic genes required for alternate carbon sources such as sucrose, maltose and galactose. Moreover, it impacts the remodeling and restructuring of chromatins and adaptation of cells to stress [41]. Snf1 kinase activity is activated at low glucose levels and inhibited in the presence of high glucose levels [40]. Snf1 causes phosphorylation of Mig1, and moves it to the cytoplasm during glucose starvation [34,40]. The role of Glc7 in CCR is antagonistic to that of Snf1 [39,42] (Figure 2). Glc7 plays its role in controlling various processes and has regulatory subunit Hex2/Reg1 for glucose-specific repression [42,43]. Hex2/Reg1 causes inhibition of Snf1 kinase by dephosphorylation depending upon glucose signal [26,42,44]. Therefore, the exquisite preference of glucose for yeast as a carbon source lays in its numerous, sophisticated mechanisms that it has developed to identify the presence of glucose and to adjust to multiple cellular functions accordingly.
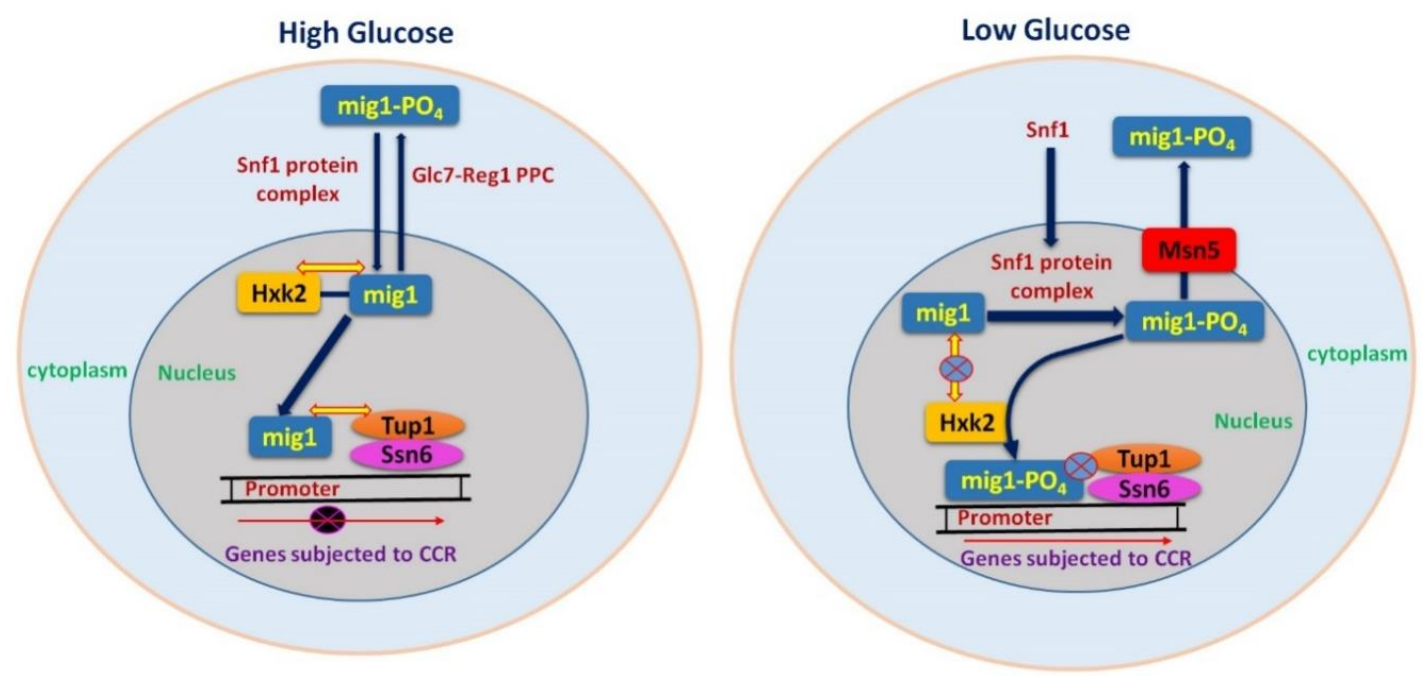

Figure 2. CCR regulation mechanism in S. cerevisiae.

$\Longleftrightarrow$ represents protein interaction in the nucleus, mig1 and hxk2, Ssn6-Tup1 co-repressor complex and mig1. Shows that there is no protein interaction, mig1 and hxk2, Ssn6-Tup1 co-repressor complex and mig1 and between Ssn6-Tup1 co-repressor complex and promoter gene. represents the inhibition of transcription [34,45-48]. During high glucose conditions, inactive Snf1 cannot cause phosphorylation of Mig1 and cellular movement of Mig1 is dependent on Glc7-Reg1 complex; whereas during low glucose levels Snf1 will be active and cause direct repression of Snf1, which will be unable to repress the CCR subjected genes. 
Table 1. Glucose sensing comparison between S. cerevisiae and filamentous fungi.

\begin{tabular}{|c|c|c|c|}
\hline $\begin{array}{l}\text { Nature/Kind of } \\
\text { Glucose Sensor }\end{array}$ & $\begin{array}{l}\text { Sensor/Sensors } \\
\text { in S. cerevisiae }\end{array}$ & $\begin{array}{l}\text { Sensor/Sensors in } \\
\text { Filamentous Fungi }\end{array}$ & Function in Filamentous Fungi \\
\hline Transporter & Snf3, Rgt2 & $\begin{array}{c}\text { Rco3 } \\
(\text { N. crass } a)\end{array}$ & $\begin{array}{l}\text { Rco3 in N. crassa might perform the same role as } \\
\text { compared to yeast proteins but structure of Rco3 is } \\
\text { different. It may have wider role than yeast proteins } \\
\text { in CCR which only regulate hexose transporters [49]. }\end{array}$ \\
\hline \multirow[t]{2}{*}{ Hexokinase } & \multirow{2}{*}{$\begin{array}{l}\text { Glk2, Hxk1, } \\
\text { Hxk2 }\end{array}$} & $\begin{array}{l}\text { HxkA, GlkA } \\
\text { (A. nidulans) }\end{array}$ & $\begin{array}{l}\text { No evidence showed direct role of a single } \\
\text { hexokinase like yeast to start CCR but } \\
\text { phosphorylation is required [50]. }\end{array}$ \\
\hline & & $\begin{array}{l}\text { HxkC, HxkD } \\
\text { (A. nidulans) }\end{array}$ & $\begin{array}{l}\text { Show response in carbon starved conditions while } \\
\text { not involved in CCR [51]. }\end{array}$ \\
\hline \multirow{6}{*}{$\begin{array}{l}\text { G-protein } \\
\text { coupled receptor }\end{array}$} & \multirow{6}{*}{$\begin{array}{l}\text { Gpr1, Gpa2 } \\
(\mathrm{G} \alpha 3)\end{array}$} & $\begin{array}{l}\text { Gpr4, GCNA1-3 (G } \alpha 1-3) \\
\text { (N. crassa) }\end{array}$ & $\begin{array}{l}\text { In response to glucose the } G \text { protein coupled } \\
\text { receptor GPR } 4 \text { play role in cAMP signaling. While } \\
\text { GPR4 in yeast interacts with } G \alpha 1 \text { instead of } G \alpha 3 \text {, } \\
\text { and } G \alpha 1 \text { through } G \alpha 3 \text { play role in nutrient sensing. }\end{array}$ \\
\hline & & $\begin{array}{c}\text { BCG3 }(\mathrm{G} \alpha 3) \\
\text { (Botrytis cinerea) }\end{array}$ & $\begin{array}{l}\text { During germinating conidia has function in cAMP } \\
\text { signaling/carbon sensing [52]. }\end{array}$ \\
\hline & & $\begin{array}{l}\text { GanB }(\mathrm{G} \alpha 3) \\
\text { (A. nidulans) }\end{array}$ & $\begin{array}{l}\text { During germinating conidia has function in cAMP } \\
\text { signaling/carbon sensing [53]. }\end{array}$ \\
\hline & & $\begin{array}{c}\text { GasC }(\mathrm{G} \alpha 3) \\
\text { (Penicillium marneffei) }\end{array}$ & $\begin{array}{l}\text { Has no role in nutrient sensing but essential for } \\
\text { germinating conidia [54]. }\end{array}$ \\
\hline & & $\begin{array}{c}\text { Gpr4 } \\
\text { (C. neoformans) }\end{array}$ & $\begin{array}{l}\text { Homologous to yeast Gpr1 but has no role glucose } \\
\text { signaling [55]. }\end{array}$ \\
\hline & & $\begin{array}{c}\text { Gpa1 (G } \alpha 3) \\
\text { (Cryptococcus neoformans) }\end{array}$ & $\begin{array}{l}\text { Involved in cAMP signaling in response to glucose } \\
\text { and melanin production [56]. }\end{array}$ \\
\hline
\end{tabular}

\subsection{CCR of Filamentous Fungi and Differences with S. cerevisiae}

Glucose sensing among filamentous fungi involves GPCR and G $\alpha$ subunits [57-59]. These proteins play similar roles in activating cAMP, irrespective of their functional differences in signaling pathways among various filamentous [60,61]. GPR4, the GPCR in N. crassa, plays a similar role as Gpr1 of yeast (activates adenylate cyclase in response to glucose and causes increment of cAMP) [60]. However, this protein couples with $\mathrm{G} \alpha 1$ subunit, as compared to $\mathrm{G} \alpha 3$ (a heterotrimeric protein of yeast). $\mathrm{G} \alpha 3$ subunit of Botrytis cinerea and A. nidulans plays an important role in cAMP signaling, carbon nutrient sensing and conidial germination [52,53]. Similarly, cAMP production in Cryptococcus neoformans is controlled by $\mathrm{G} \alpha 3$ subunit [56]. The cAMP-dependent protein kinase A (PKA) plays an important role in CCR and fungal growth by regulating primary metabolism and CCR. PKA has two catalytic subunits encoded by $P k a A$ and $P k a B$ in $A$. nidulans, where a major role is played by $P k a A$ (via Ras proteins and GPCR) inside the cell [59,62]. Adenylate cyclase, after activation by Ras protein and GPCR pathway, leads to increased cAMP production, which binds to PkaA and releases active catalytic subunit which phosphorylate downstream targets $[59,63]$. The PKA activity in A. fumigatus increases upon the presence of glucose [64]. In A. fumigatus, deletion of the gene coding for $p k a C 1$ or $p k a C 2$ (catalytic subunit of the PKA), reduces fungal growth on glucose, which further supports that PKA plays a significant role in the fungal glucose metabolism [65].

The role of hexokinases is very prominent as only one gene encoding hexokinase is enough for growth on glucose in filamentous fungi. GlkA and $f r A / h x k A$ encode catalytic hexokinases in A. nidulans and A. fumigatus [11,66,67]. Unlike yeast, either one of glkA or frA can cause glucose mediated CCR repression in A. nidulans, and both have to be deleted to block repression $[66,67]$. Rco3 of N. crassa is a glucose transporter homolog that has an extended C terminus [49], like Rgt2 and Snf3. Rco3 was first studied in N. crassa where its deletion led to a significant reduction in conidiation in submerged cultures having high levels of glucose, xylose, glycerol, or fructose [68]. The Rco3 mutants show altered response during low and high level glucose transport activity [49]. Based on these observations, it was proposed that Rco3 also functions as a glucose sensor. Mutation of MstA 
(high-affinity glucose transporter) also result in altered expression of other genes encoding hexose transporters in Aspergillus niger (mstF expression is reduced while mstC is increased) [69].

CCR of filamentous fungi has many similarities to that of yeast, but there are some glaring differences as well. The mechanism of CCR is more complex in filamentous fungi as compared to S. cerevisiae, reflecting the differences in lifestyle and ability of filamentous fungi to utilize a broad range of C-sources, such as pentoses. In contrast to $S$. cerevisiae, CCR in filamentous fungi is not only regulated by glucose, but also by high concentrations of other monosaccharides that also affect nuclear localization of CreA orthologs [70]. The role of G $\alpha$ subunits and GPCR are quite similar, however, the interaction of GPCR in filamentous fungi with signaling components still remains uncertain $[60,61]$. Relief of CCR in filamentous fungi occurs only in the presence of inducers and during metabolic stress or carbon limitation, while it is not the case in yeast [70]. CreA, the most important factor of CCR in A. nidulans is a homologue of yeast Mig1. As with S. cerevisiae Mig1, phosphorylation also affects the localization and function of CreA [71]. The presence of cellulose activates SnfA (homologue of yeast snf1), which causes CreA phosphorylation, and moves it to the cytoplasm (inactivation of CCR) (Figure 3). This is in contrast to yeast, where phosphorylation moves Mig1 into the nucleus (Figure 2). The presence of glucose inactivates SnfA, resulting in dephosphorylated CreA which returns to the nucleus [72].

In A. nidulans ubiquitination is involved during CCR, while in S. cerevisiae there are no such regulatory genes for this mechanism. Activation of CreA involves addition and subsequent removal of ubiquitin, mediated by CreD-HulA ubiquitin ligase complex and the CreB-CreC DUB complex, respectively (Figure 3) [3,73]. The co-repressor proteins, Tup1 and Ssn6, of yeast have RcoA and SsnF homologues in A. nidulans respectively [74]. RcoA is a WD repeat protein of $A$. Nidulans and is a homologue of Rco1of N. crassa [75]. CCR in S. cerevisiae involves the co-repressor Tup1, while the role in CCR of the orthologous Rco1 of $N$. crassa has not been established. Rco1 does regulate pleiotropic development and gene expression [76,77]. Similarly, in A. nidulans, deletion of RcoA does not eliminate CCR, but does alter chromatin structure of carbon catabolite repressible promoters (alcA, alcR and prnD-prnB) [74]. Interestingly, deletion of $S s n F$ (the putative RcoA partner) is lethal in A. nidulans [74]. Therefore, it can be proposed that RcoA may play an indirect role in CCR by virtue of its chromatin modulation activity. Therefore, a cohesive picture of glucose signaling has yet to emerge in filamentous fungi.

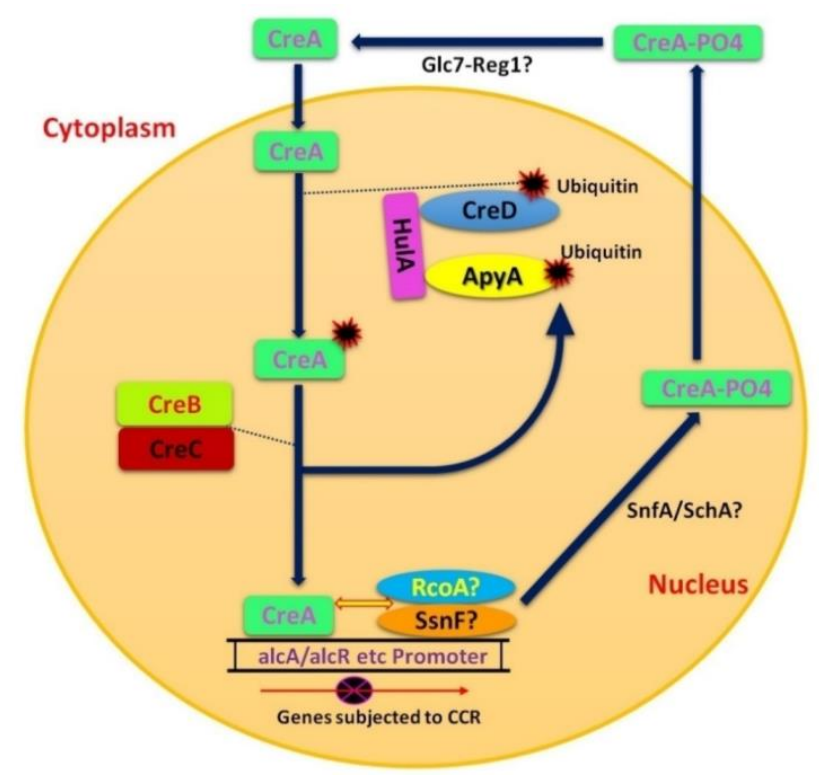

Figure 3. Proposed CCR regulation mechanism in Aspergillus nidulans. Model representing interaction of CreA, CreB, CreC, CreD, HulA, ApyA, RcoA, SsnF, SnfA and Glc7-Reg1 complex in CCR. CreD along 
with HulA/ApyA is required in conjugating ubiquitin and CreA. ApyA forms strong protein-protein interaction with HulA than CreB [8,57]. However CreD and ApyA are both present in A. nidulans. CreB-CreC complex is required to remove ubiquitin from $\mathrm{CreA}-\mathrm{Ub}$ complex so that $\mathrm{CreA}$ can repress CCR subjected genes. CreB helps in the removal of ubiquitin from CreA to prevent degradation of CreA by proteasome $[8,78,79]$. The role of RcoA and SsnF in binding with the promoters of glucose repressible genes along with $\mathrm{CreA}$ is still unclear $[75,80]$. However the deletion of RcoA and SsnF can be lethal for A. nidulans [74]. SnfA and SchA can play synergistic or overlapping role in regulating CreA derepression [31].

\section{Key Regulators of CCR in Filamentous Fungi}

The role of the key regulators of CCR has already been briefly described above. However, we will try to provide a comprehensive description of these factors here.

\subsection{CreA/Cre1}

In most fungal species, the zinc finger transcription factor CreA/CRE1/Mig1 mediates different aspects of CCR [5,80-82]. CreA has been identified in many filamentous fungi such as Metarhizium anisopliae, Sclerotinia sclerotiorum, B. cinerea, Neurospora crassa and Cochliobolus carbonum [83-85]. CreA-encoded protein contains zinc finger of Cys2-His2 class, common S (T) PXX motifs, alanine rich region and acidic domain [70,86]. It binds to 5'-SYGGRG-3' on DNA, and the amino acid sequence of its zinc finger region is similar to yeast Mig1, and Wilms tumor suppressor protein [15].

CreA proteins of all fungi contain a highly conserved region of 42 amino acids which is rich in proline, threonine and serine residues [87]. In T. reesei and Aspergillus spp. a conserved region of CreA was identified to be essential for growth on carbon, lipid and nitrogen sources [5]. In $A$. nidulans, CreA plays a particular role in regulating the utilization of arabinan, xylan, ethanol and proline $[5,16]$. CreA mutants of $A$. nidulans, show changes in enzyme activity, depression of primary metabolism and metabolite profile change [88]. In filamentous fungi, $C r e A$ is also related to important pathways of growth and polarity. CreA of $A$. nidulans binds to the promoter region at the DNA sequence 5'-SYGGRG-3' of $x \ln A$ and $x \ln D$ (xylanase encoding genes) and causes their direct repression [15]. The expression of $x \ln R$, which encodes the major inducer of xylanases, and to some extent cellulase-encoding genes (Table 2) is also repressed by CreA [4,15,89]. All genes which are regulated by $x \ln R$ can be indirectly repressed by CreA [86]. The transcription factors, AraR and ARA1 for arabinose utilization genes (Table 2), can also be repressed by CreA $[5,86,90]$.

CreA mediates various alternative carbon-utilizing systems, because it is a global regulator of CCR. The gene AreA, encodes a protein AreA that is a positive regulator and causes ammonium derepression [91]. In case of any loss of functional mutation in AreA, the strain will be unable to grow on D-glucose and alternative nitrogen sources since the enzymes dependent on ammonium will not be expressed during ammonium repression. However, in a few instances proline and acetamide act as nitrogen and carbon sources and their enzymes are subjected to ammonium repression and CCR [91]. In the absence of D-glucose, the AreA mutant strains can grow on media containing acetamide or proline as the only sources of carbon and nitrogen, respectively, but they cannot grow on D-glucose as the only source of carbon and nitrogen [91,92]. It can therefore be supposed that carbon and nitrogen repression are closely related phenomena.

CreA regulation, both at transcriptional and post transcriptional levels, need further attention as little work has been done on this aspect $[5,15,93,94]$. Ubiquitination and phosphorylation cause pre- and post-transcriptional modification which may control the localization as well as function of CreA [5]. Phosphorylation of Cre1 in T. reesei is essential for DNA binding though Cre1 is not apparently regulated by Snf1 homolog $[95,96]$. For this, we propose that there are multiple binding motifs among CreA/Cre1 target promoters e.g., in A. nidulans alcR promoter there are nine CreA binding sites [97,98], also, H. jecorina xyr1 promoter possesses ten Cre1 binding sites [99]. Deletion of CreA binding sites from 
aguA promoter of $A$. niger enhanced the gene expression [100]. However, it was not predicable that the promoters only need the presence of $5^{\prime}$-SYGGRG-3' motif or it may require additional regulatory factors necessary for binding solely to $\mathrm{CreA} / \mathrm{Cre1}$. In N. crassa, Cre1 not only binds to the promoter region motifs but also competes with the regulatory factors during cellulolytic conditions [101,102]. The strains, which have lost functional mutation of Cre1 homologs, show morphological problems while growing on carbon-rich sources. Various studies regarding the role of CreA have been confined to the transcription level regulation during CCR. However some studies suggest a more cell-wide regulatory role of this transcription factor $[4,11,93]$. Recent observations have revealed that CreA is not a direct target of $\mathrm{CreB}$, though $\mathrm{CreA}$ is a phosphorylated protein but there was no evidence of its ubiquitination [73]. Despite this, the molecular mechanisms of CreA regarding its repression activity as well as $\mathrm{CreB}-\mathrm{CreC}$ interaction with this regulatory setup still remain largely ambiguous [3].

Table 2. Transcription factors of filamentous fungi responsible for carbon source utilization.

\begin{tabular}{|c|c|c|}
\hline Transcription Factor & Major Role & Fungi \\
\hline CreA/CRE1 & CCR & Aspergillus spp., N. crassa, Trichoderma spp., etc. [70] \\
\hline $\mathrm{BglR} / \mathrm{COL}-26$ & $\begin{array}{l}\text { Sugar sensing and regulation of } \\
\text { glucosidase expression }\end{array}$ & N. crassa, Trichoderma reesei [103-105]. \\
\hline VIB1 & $\begin{array}{l}\text { C-derepression, may also play } \\
\text { role in cellulases induction }\end{array}$ & N. crassa $[104]$ \\
\hline CLR-1/ClrA & Cellulose utilization & N. crassa, Aspergillus spp. [106-108]. \\
\hline CLR-2/ClrB/ManR & Cellulose utilization & $\begin{array}{l}\text { N. crassa, Aspergillus spp., Talaromyces cellulolyticus, } \\
\text { Peniciulium oxalicum [106-108] }\end{array}$ \\
\hline ACE2, ACE3 & Cellulose utilization & T. reesei $[109,110]$ \\
\hline McmA & Cellulase regulation & A. nidulans [111] \\
\hline ACE1 & Cellulase repression & T. reesei $[112,113]$ \\
\hline XlnR/XLR1/XYR1 & Hemi-cellulose utilization & $\begin{array}{l}\text { Aspergillus spp., Fusarium spp., Trichoderma spp., } M \text {. } \\
\text { oryzae, Protubera canescens, N. crassa, T. cellulolyticus [89] }\end{array}$ \\
\hline WC-1/BLR1, WC-2/BLR2 & Hemi-cellulose utilization & Trichoderma spp., N. crassa [114-116] \\
\hline HCR-1 & Hemi-cellulase repressor & N. crassa [117] \\
\hline AraR & L-Arabinose utilization & Aspergillus spp. [118,119] \\
\hline ARA1 & L-Arabinose utilization & M. oryzae [120] \\
\hline AmyR & Starch utilization & Aspergillus spp. [121,122] \\
\hline MalR & Maltose utilization & Aspergillus spp. [123,124] \\
\hline $\mathrm{ClbR}$ & Cellobiose utilization & Aspergillus aculeatus $[125,126]$ \\
\hline GalR & D-Galactose utilization & A. nidulans $[127,128]$ \\
\hline GalX & D-Galactose utilization & Aspergillus spp. [129] \\
\hline GaaR & Galacturonic acid utilization & B. cinerea, Aspergillus niger $[130,131]$. \\
\hline GaaX & Galacturonic acid repressor & A. niger [131] \\
\hline XPP1 & Xylanases repressor & T. reesei $[132,133]$ \\
\hline HAP complex & $\begin{array}{l}\text { Carbohydrate-Active enZymes } \\
\text { regulation (CAZy regulation) }\end{array}$ & Aspergillus spp., Trichoderma spp., N. crassa [134-137] \\
\hline RhaR & L-Rhamnose utilization & Aspergillus spp. [138,139] \\
\hline InuR & Inulin utilization & A. niger $[140,141]$ \\
\hline
\end{tabular}

\section{2. $\mathrm{CreB}$ and $\mathrm{CreC}$}

Ubiquitination plays an important role during CCR by altering protein function during macromolecular assembly. Ubiquitin acts as a marker either by modifying the function of a protein or tagging it for destruction by specific proteasome [79]. Deubiquitination enzymes activate specific transcription factors by targeting their domains. The ubiquitination ligases and deubiquitination enzymes interact with each other and control the transcription factors of CCR mechanism $[5,16,73]$. 
CreB of $A$. nidulans is a homologue of human $U B H 1$ gene, which is involved in ubiquitination during CCR [78]. CreB contains 6 DUB coiled regions for recognition of the substrate, and 4 PEST sequences which act as a signal for proteolysis $[78,79]$. However, $\mathrm{CreC}$ is a regulatory gene which encodes a 630 amino acid polypeptide rich in proline near its N-terminus and has five WD 40 repeat motifs at its C-terminus [3,142]. Protein-protein interaction is facilitated by the WD 40 repeat regions, which form a propeller-like region [143].

$\mathrm{CreC}$ has a regulatory mechanism in multicellular eukaryotes, which is suggested by the presence of $\mathrm{CreB}$ and $\mathrm{CreC}$ homologues in mouse and humans but not in S. cerevisiae [81,142]. Co-immunoprecipitation experiments have shown that $\mathrm{CreB}$ and $\mathrm{CreC}$ proteins function together as a complex during repression or derepression condition. It was proved that $\mathrm{CreB}-\mathrm{CreC}$ deubiquitination complex has its role in CCR as deletion of $\mathrm{Cre} 2$ and $\mathrm{CreB}$ in $T$. reesei and $A$. oryzae respectively enhanced the secretion levels of hydrolytic enzymes $[13,144]$. The $C$ reB-CreC deubiquitination complex eradicates ubiquitin moieties from CreA and other substrates thereby modifying the protein [79]. However, CreB overexpression partially compensates the deficiency of $\mathrm{CreC}$, but overexpression of $\mathrm{CreC}$ does not compensate for $\mathrm{CreB}$ deficiency suggesting that $\mathrm{CreB}$ acts downstream of $\mathrm{CreC}$ protein. We found that $\mathrm{CreC}$ in Magnaporthe oryzae plays an important role in vegetative growth, conidiation and appressorium formation. $\mathrm{Cre} C$ mutation hinders penetration and reduces infection, which results in attenuated virulence. $\mathrm{CreC}$ mutants represented sensitivity towards allyl alcohol in the presence of glucose and utilization of secondary carbon sources was not fully repressed by 2-deoxyglucose, which affects CCR. The genes encoding cell wall degradation enzymes such as feruloyl esterase, $\beta$-glucosidase and exoglucanase in $\mathrm{MoCreC}$ mutants were also upregulated. Therefore, it can be depicted that $\mathrm{CreC}$, in addition to gene regulation, plays a much wider role in growth, development as well as virulence of the fungus [3].

\section{3. $\mathrm{CreD}$}

CreD is involved in the ubiquitination of CreA after which CreB-CreC DUB complex comes into play (Figure 3) [8]. HulA is a homologue of Rsp5 (ubiquitin ligase of yeast) in A. nidulans and so, CreA might be ubiquitinated by CreD-HulA ubiquitination ligase complex which may change the conformity of CreA protein in order to be targeted by proteasomes (Figure 3) [8,73]. Boase and Kelly [8] found another gene, $A p y A$, which is relatively similar to $\mathrm{CreD}$ but shows stronger interaction with HulA than CreD. Therefore, it can be supposed that $A p y A$ is a result of gene duplication during evolution and it could possibly play its role in ubiquitination (Figure 3 ).

CreD may act opposite to the CreB-CreC DUB complex as CreD34 suppresses some mutant phenotypes of $\mathrm{CreB}$ and $\mathrm{CreC}$ [8]. In a diploid strain $\mathrm{CreD} 34$ is recessive to $\mathrm{CreD}$; however, genetic analysis depicts that $\mathrm{CreD}$ has a close connection with $\mathrm{CreC}$ on chromosome11 [145]. CreD encrypts a protein that has arrestin N and arrestin C domains, two PXY motifs and one PPXY motif when cloned by complementation and physically analyzed [8]. The PPXY and PXY motifs are respectively rich in proline and basic sequences. These features are found in transcription factors and are actively involved in protein-protein binding [146-148]. The mutation in CreD34 inhibited other aspects of mutational $\mathrm{CreB}$ and $\mathrm{CreC}$ phenotypes, such that the derepression of genes alc $A$ and fac $A$ as analyzed through the allyl alcohol and fluoroacetate sensitivity found in CreC 27 strains [145]. The CreD34 mutant strain shows greater resistance to flouroacetamide and glucose than the wild type and this seems that $\mathrm{CreD} 34$ mutant has higher repression of CCR enzymes. The suppression of the $\mathrm{CreB}$ and $\mathrm{CreC}$ mutant phenotypes by $\mathrm{CreD} 34$ concludes that $\mathrm{CreD}$ has implications in reverse process to deubiquitination role of the CreB-CreC protein complex [8].

\subsection{Snf1}

Phosphatases and protein kinases help in the addition or removal of phosphate group to their target proteins and regulate their structure, function, and localization. They can play a major role in many processes such as functional regulation, metabolism, cell fate and secretion [71]. The protein 
kinase Snf1 stands for "Sucrose Non Fermenting", which was named after a mutant unable to ferment sucrose but still can ferment glucose [40,149]. The gene Snf1 was first studied in S. cerevisiae, which is a homologue of the mammalian cyclic Adenosine Mono Phosphate (cAMP)-dependent Protein Kinase AMPK [150]. It plays a significant role in sensing energy status, and its homologs are present in all eukaryotes such as fungi, plants, and animals $[150,151]$. Snf1 controls CCR, by encoding a protein kinase that functions in the glucose derepression pathway in S. cerevisiae, while in some plant pathogenic fungi it plays vital roles in regulating and repressing the Cell Wall Degrading Enzymes (CWDE) $[6,23,152]$.

Snf1 causes phosphorylation of its downstream repressor Mig1 and also helps in the derepression of glucose-repressed genes during low level of glucose [152]. Therefore, when glucose is depleted from the medium, Snf1 releases the CCR. On the other hand, a high level of phosphorylated glucose inactivates snf1, making it unable to phosphorylate Mig1, and Mig1 will remain occupied in the nucleus [5,70]. Interestingly, Casein kinase II causes the phosphorylation of Cre1 transcription factor of T. reesei at Ser241 within its acidic domain; this is an essential post-transcriptional modification for DNA binding and repression by Cre1 [95]. However, Snf1 homolog of Hypocrea jecorina (T. reesei) was unable to phosphorylate Cre1 homologue [96]. Also, there is no solid evidence of direct phosphorylation of CreA in A. nidulans, but some findings propose that kinases can play an important role in controlling CreA cellular localization [5]. Even under glucose-rich conditions, deletion of two kinases, SchA (homologue of S. cerevisiae Sch9) and SnfA (homologue of Snf1), keeps CreA occupied within the nucleus [31].

The Snf1 ortholog in U. maydis has functional similarity with Snf1 of S. cerevisiae, and its mutant surprisingly produced higher expressions of pectinases and endonucleases than the wild type under derepression conditions, which means that it negatively regulates these genes. In filamentous fungi, is still unclear whether there is a conserved mechanism for carbon catabolite derepression by Snf1; even if it exists, the Snf1 pathway may still control some developmental processes as well as the gene expression of CWDEs [153].

\section{Chromatin Modification and CCR}

Gene regulation also involves a second level of complexity ruled by epigenetics and access to chromatin (such as acetylation, methylation, and histone modification) [154-156]. Successful CCR operations require proper access to heterochromatin in order to control gene expression, generally organized through CCAAT box (Hap complex), acetylation levels and methylation [157-160]. The Hap complex is believed to be significant for the generation of an open chromatin structure, which enables full transcriptional activation of certain promoters $[137,161]$. The CCAAT-binding complex was first described in S. cerevisiae, and it consists of Hap2, Hap3, Hap4, and Hap5 proteins. Their homologues have been identified in different filamentous fungi such as N. crassa (HAP5), T. reesei (HAP2, 3, 5) and A. nidulans (AnCF) [134]. In filamentous fungi, CCAAT sequences lie in the promoters of respiratory genes, cellulase, hemicellulose and ligninolytic encoding genes [162].

In Cbh2 of T. reesei, the presence of this sequence in the promoter region was found to be necessary for gene expression [135]. Furthermore, CRE1, HAP complex, and an unknown GTAATA binding protein affects nucleosome positioning, and influences the accessibility to the TATA box for transcription initiation of cbh2 (Table 2) [161]. During repression conditions, CreA/CRE1 directly affects chromatin structure (acetylation, methylation, nucleosome position, packaging etc.) in T. reesei and A. nidulans [163-166]. CRE1 of T. reesei organizes the local chromatin structure or nucleosome positioning in the xyr1 promoter as well as in the cellulases cbh1and cbh2 during repressing conditions; however its loss results in less dense chromatin structure [164-166]. In A. nidulans CreA was found to cause chromatin remodeling through histone deacetylation [163]. Gene expression is also affected by acetylation levels, which influence the access to chromatin. Consistent with this, deletion of the histone acetyltransferase, GCN5, in T. reesei severely affects the acetylation levels, which results in impaired growth, morphogenesis, and expression of cellulase-encoding genes [167]. 


\section{Impact of CCR Components on Fungal Behavior}

The components of CCR are integrated for regulation of fungal growth, development, and pathogenesis, where glucose status is one signal that conveys information about the environment.

\subsection{Regulation of Fungal Growth}

Cell-wide regulatory role of CCR is most extensively studied among Aspergillus spp., T. reesei and $N$. crassa $[16,168]$. CreA has significant influence in fungal development and growth as it reduces the activity of b-galactosidase in A. nidulans. Ilyés et al. [169] have observed that the growth rate of $A$. nidulans is dependent on CCR. Although in bacteria and S. cerevisiae growth rate and CCR are dependent on application of glucose dilutions, which has considerable effect on the growth rate, but the Crabtree effect in yeast and CCR mechanism of bacteria are different from filamentous fungi [170-172]. CreA mRNA represented an intricate expression profile during northern blot analysis. Monosaccharides when added to carbon deficient culture of $A$. nidulans stimulated CreA transcript formation within a short period of time. The above findings suggest that, in order to achieve CCR, a higher transcript level of $\mathrm{CreA}$ is essential and depends on glucose transportation as well as product of $\mathrm{CreB}$ gene at least partially [173]. Snf1 plays a significant role in the growth, development and sporulation of yeast, depending on different nutrient signals [174]. Similarly, the homolog of Snf1 in M. oryzae (MoSnf1) functionally restored the growth defects of yeast Snf1 mutant [153].

\subsection{Regulation/Utilization of Non-Glucose Sources}

Filamentous fungi degrade plant cell wall polymers such as cellulose, hemicellulose and lignin by secreting hydrolytic enzymes [101,110,175-179]. The production of these enzymes is reduced or suppressed when glucose is easily available in the environment due to suppression or repression of genes encoding these enzymes [82]. Therefore, during enormous availability of glucose, the CWDE production is repressed by CCR [104]. CWDE activity is under control of glucose repression in Cochliobolus carbonum [85,180]. Deletion of ccSnf1 (Snf1 homolog) in C. carbonum resulted in down regulation of CWDE [180]. Interestingly, deleting FoSnf1 in vascular wilt pathogen Fusarium oxysporum produced similar results [181]. In addition to regulating gene transcription, Snf1 also regulates the transport and storage of carbohydrates and fatty acids through phosphorylation of related proteins [182].

There are lots of reports on CreA regulation of CWDEs [85,153,180,183]. CreA homologue in F. oxysporum regulates the CWDEs and isocitrate lyase production $[67,70,184]$. In T. reesei and A. nidulans, CreA/Cre1 cause gene regulation in xylan, xylose, arabinose, ethanol and proline utilization $[5,16,185]$. The transcriptional regulation of genes by CreA is in a "double-lock" manner $[183,186]$. The genes for ethanol regulation in A. nidulans consist of two major structural genes aldA (aldehyde dehydrogenase), alc $A$ (alcohol dehydrogenase) and transacting regulatory gene alcR [97,187-189]. AlcR is directly repressed by $\mathrm{CreA}$ and alcA and ald $\mathrm{A}$ are repressed when $\mathrm{CreA}$ competes with alcR binding promoter sequence $[98,186,190,191]$.

Likewise, CreA represses the xylanolytic system by direct repression of $x \ln r$ and $x \ln A$, which are pathway-specific regulator and structural genes respectively $[15,89,185]$. A niger has four genes involved in xylose regulation, which are faeA (feruloyl esterase gene), $x \ln B$ (endoxylanase gene), aguA ( $\alpha$-glucuronidase gene) and $x \ln D$ ( $\beta$-xylosidase gene). The xylanolytic genes are generally repressed in the wild type strains while CreA mutants show higher xylose accumulations $[15,89,185]$. T. reesei $($ H. jecorina); Cre1 represses the cellulose degrading enzymes by binding the cellobiohydrolase 1 ( $c b h 1$ ) promoter region, and also represses xylanase activity by binding to the xyn1promoter $[15,99,164,185,192-194]$. XprG is a transcriptional activator of extracellular protease, PrtA. However, production of extracellular protease remains unaltered following the supplementation of exogenous protein in the medium, irrespective of carbon status. Extracellular protein level increases in a carbon-deficient medium only due to mutations in $\mathrm{CreA}, \mathrm{CreB}, \mathrm{CreC}$ [11]. 


\subsection{Virulence}

The factors involved in CCR of filamentous fungi may directly or indirectly play their roles in pathogenicity on insects, plants and animals. In order to penetrate and enter the host plant cell, fungi release chitinases, esterases and proteinases that degrade the cells cuticle [195,196]. Virulence in entomopathogenic fungi can be increased by over expressing the chitinase Bbchit1 and subtilisin-like protease Pr1A [197]. Enzymes for cuticle degradation in Metarhizium anisopliae might be regulated by CRR1 which is equivalent in function to CreA of $A$. nidulans $[198,199]$. CreA from Beauveria bassiana named $B b C r e 1$ is involved in carbon source uptake, conidiation, and can impact on virulence by regulating penetration mechanism [200]. Severe symptoms may result due to overexpression of CCR encoding genes in Alternaria citri (black rot of citrus fruit) [1]. Wild type strain of $A$. citri only showed symptoms inside the central region of fruit, while the overexpression mutant of $A$. citri (AcCreA) produced severe symptoms in the central region as well as juice sac areas [1].

CreA homologue in F. oxysporum functions along with F-box protein (Frp1) in order to regulate carbon utilization, and most importantly required for the fungal pathogenicity $[67,70,184]$. Cre1 mutation in F. oxysporum f. sp. lycopersici can restore pathogenicity defects of Frp 1 deletion mutant (because Frp1 is required for pathogenicity of F. oxysporum f. sp. Lycopersici on tomato). The Frp1 mutant does not express the cell wall degradation genes and ICL1 (a gene encoding an enzyme for assimilation of C2 carbon sources) [184]. This suggests that both Frp1 and Cre1 proteins are significant for regulating transcription of CCR genes. In $M$. oryzae, there are three mediators of CCR that are inhibitor proteins, namely Nmr1-3, sugar sensor Tps1 and multidrug and toxin extrusion (MATE) — family pump mdt1. The activities of MATE-Family, Nmr1-3, and Tps1 are crucial for glucose metabolism during the infection process. Glucose-6-phosphate is sensed by Tps1, which inactivates Nmr1-3 and initiates the CCR. Glucose assimilation is regulated by Mdt1, which is also important for pathogenicity, sporulation and nutrient utilization. The mutational studies of all the three mediators showed early expression of CWDEs, which suggests their critical role during pathogenicity of M. oryzae [201,202].

Deletion of nearly 21 genes except $C r e A, X \ln R$, and $S n f 1$ kinase homologs did not affect the virulence in Alternaria brassicicola (necrotrophic fungal pathogen). A. brassicicola causes the black spot disease of Brassicas. A. brassicicola expresses CWDEs in a unique way as deletion of only XlnR but not CreA, Snf1 or Ste12 can reduce the ability of glucose utilization [203]. Verticilium dahliae (soil borne fungi causing vascular wilt) $V d S n f 1$ is a sucrose non-fermenting 1 gene that regulates CCR. The $V d S n f 1$ mutant was unable to produce CWDEs, and had considerably reduced growth on galactose or pectin as compared to xylose, sucrose or glucose medium. Moreover, VdSnf1 is considered important for CCR and colonization of cotyledons, stem and roots of tomato and eggplant [204]. The pathogenicity of C. carbonum was also reduced on deletion of $c c S n f 1$ (Snf1 homolog) [180]. The snf1 deletion mutant of $M$. oryzae (Dmosnf1) showed reduced pathogenicity, few and abnormally shaped conidia than the wild type which suggest that it plays vital role in sporulation and pathogenicity of M. oryzae [153].

In almost all analyzed fungi, deletion of $C r e A$ can result in impaired colony morphology, with few aerial hyphae and spores $[102,205,206]$. While CreA mutation in the case of P. chrysogenum and F. oxysporum can be lethal for these fungi [3,207]. We have also observed that M. oryzae, CreA null mutants grow slower than the wild type in a glucose-independent manner, which suggests some faults in CCR. The CCR defects were further supported by resistance of CreA mutants to 2-deoxyglucose and inefficient glucose transport. In addition, production of conidia was reduced, conidial germination and appressorium formation were delayed which resulted in less virulence among the mutants (non-published data). Recently, we found that MoCreC plays significant role in growth, conidiation and pathogenicity of M. oryzae [3]. Currently, Beattie et al. [208] proposed a model for the role of $\mathrm{CreA}$ and disease progression of invasive aspergillosis, which describes that CCR in an environmental filamentous fungus is dispensable for the initiation of pulmonary infection but essential for infection maintenance and disease progression. They revealed that fungal fitness and invasion of microenvironment requires the support of CCR mediated genetic network in A. fumigatus. 


\section{Concluding Remarks}

CCR has optimized carbon utilization as an evolved trait in filamentous fungi [209]. CCR provides clues on how filamentous fungi cope with different nutrient situations. The genome machinery of CCR may involve various factors such as $\mathrm{CreA}, \mathrm{CreB}, \mathrm{CreC}, \mathrm{CreD}, \mathrm{HulA}, \mathrm{Apy} A, \mathrm{Rco} A, \operatorname{Ssn} \mathrm{F}, \mathrm{Sch} A$ and Glc7-Reg1 [8,40,73]. CreA activity is regulated via ubiquitination and deubiquitination [5]. Although the roles of $\mathrm{CreB}, \mathrm{CreC}$ and $\mathrm{CreD}$ are well established in relation to CreA activation, some ambiguities still exist regarding the functions of HulA and ApyA in ubiquitination of CreA [73]. Formerly, it was accepted that $\mathrm{CreB}-\mathrm{CreC}$ deubiquitination complex causes activation of CreA necessary for its repression [79]. However, recent studies revealed that CreA is not a direct target of CreB; instead, CreA is a differentially phosphorylated protein with no evidence of ubiquitination [73]. It will be of immense significance to further investigate the link between CCR subjected genes and CCR complex (CreA, RcoA, SsnF) among the filamentous fungi. The role of SchA/SnfA in phosphorylating CreA and its movement towards the cytoplasm is not very convincing. Another very important aspect that needs more attention in CCR of filamentous fungi is the role of Glc7-Reg1 in dephosphorylation and mobilization of CreA back to the nucleus. Gene regulation ruled by epigenetics adds another level of complexity controlled by factors such as acetylation, methylation, and histone modification for successful operation of CCR $[155,156]$. In the future, dissecting the operation of CCR at the transcriptome, proteome and metabolome levels will be of fundamental importance to produce valuable insights for understanding CCR of filamentous fungi.

Acknowledgments: The authors gratefully acknowledge NSFC (National Science Foundation of China) Grant (31571943) for financial support.

Conflicts of Interest: The authors declare no conflict of interest. The authors declare that the research is being conducted in the absence of any commercial or financial relationships that could be construed as a potential conflict of interest.

\section{References}

1. Katoh, H.; Ohtani, K.; Yamamoto, H.; Akimitsu, K. Overexpression of a gene encoding a catabolite repression element in Alternaria citri causes severe symptoms of black rot in citrus fruit. Phytopathology 2007, 97, 557-563. [CrossRef] [PubMed]

2. New, A.M.; Cerulus, B.; Govers, S.K.; Perez-Samper, G.; Zhu, B.; Boogmans, S.; Xavier, J.B.; Verstrepen, K.J. Different levels of catabolite repression optimize growth in stable and variable environments. PLoS Biol. 2014, 12, e1001764. [CrossRef] [PubMed]

3. Matar, K.A.O.; Chen, X.; Chen, D.; Anjago, W.M.; Norvienyeku, J.; Lin, Y.; Chen, M.; Wang, Z.; Ebbole, D.J;; $\mathrm{Lu}, \mathrm{G}$. WD40-repeat protein $\mathrm{MoCreC}$ is essential for carbon repression and is involved in conidiation, growth and pathogenicity of Magnaporthe oryzae. Curr. Genet. 2017, 63, 685-696. [CrossRef] [PubMed]

4. Portnoy, T.; Margeot, A.; Linke, R.; Atanasova, L.; Fekete, E.; Sándor, E.; Hartl, L.; Karaffa, L.; Druzhinina, I.S.; Seiboth, B. The CRE1 carbon catabolite repressor of the fungus Trichoderma reesei: A master regulator of carbon assimilation. BMC Genom. 2011, 12, 269. [CrossRef] [PubMed]

5. Ries, L.N.; Beattie, S.R.; Espeso, E.A.; Cramer, R.A.; Goldman, G.H. Diverse regulation of the CreA carbon catabolite repressor in Aspergillus nidulans. Genet. 2016, 203, 335-352. [CrossRef] [PubMed]

6. Kayikci, Ö.; Nielsen, J. Glucose repression in Saccharomyces cerevisiae. FEMS Yeast Res. 2015, 15. [CrossRef] [PubMed]

7. Mogensen, J.; Nielsen, H.B.; Hofmann, G.; Nielsen, J. Transcription analysis using high-density micro-arrays of Aspergillus nidulans wild-type and creA mutant during growth on glucose or ethanol. Fungal Genet. Biol. 2006, 43, 593-603. [CrossRef] [PubMed]

8. Boase, N.A.; Kelly, J.M. A role for creD, a carbon catabolite repression gene from Aspergillus nidulans, in ubiquitination. Mol. Microbiol. 2004, 53, 929-940. [CrossRef] [PubMed]

9. Georgakopoulos, P.; Lockington, R.A.; Kelly, J.M. SAGA complex components and acetate repression in Aspergillus nidulans. G3 Genes Genom. Genet. 2012, 2, 1357-1367. [CrossRef] [PubMed] 
10. Ichinose, S.; Tanaka, M.; Shintani, T.; Gomi, K. Improved $\alpha$-amylase production by Aspergillus oryzae after a double deletion of genes involved in carbon catabolite repression. Appl. Microbiol. Biotechnol. 2014, 98, 335-343. [CrossRef] [PubMed]

11. Katz, M.E.; Bernardo, S.M.; Cheetham, B.F. The interaction of induction, repression and starvation in the regulation of extracellular proteases in Aspergillus nidulans: Evidence for a role for CreA in the response to carbon starvation. Curr. Genet. 2008, 54, 47. [CrossRef] [PubMed]

12. OBrian, G.R.; Fakhoury, A.M.; Payne, G.A. Identification of genes differentially expressed during aflatoxin biosynthesis in Aspergillus flavus and Aspergillus parasiticus. Fungal Genet. Biol. 2003, 39, 118-127. [CrossRef]

13. Hunter, A.; Morris, T.; Jin, B.; Saint, C.P.; Kelly, J. Deletion of creB in Aspergillus oryzae increases secreted hydrolytic enzyme activity. Appl. Environ. Microbiol. 2013, 79, 5480-5487. [CrossRef] [PubMed]

14. Amore, A.; Giacobbe, S.; Faraco, V. Regulation of cellulase and hemicellulase gene expression in fungi. Curr. Genom. 2013, 14, 230-249. [CrossRef] [PubMed]

15. Tamayo, E.N.; Villanueva, A.; Hasper, A.A.; de Graaff, L.H.; Ramón, D.; Orejas, M. CreA mediates repression of the regulatory gene $x \ln R$ which controls the production of xylanolytic enzymes in Aspergillus nidulans. Fungal Genet. Biol. 2008, 45, 984-993. [CrossRef] [PubMed]

16. Kubicek, C.P.; Mikus, M.; Schuster, A.; Schmoll, M.; Seiboth, B. Metabolic engineering strategies for the improvement of cellulase production by Hypocrea jecorina. Biotechnol. Biofuels 2009, 2, 19. [CrossRef] [PubMed]

17. Chen, Y.; Nielsen, J. Advances in metabolic pathway and strain engineering paving the way for sustainable production of chemical building blocks. Curr. Opin. Biotechnol. 2013, 24, 965-972. [CrossRef] [PubMed]

18. Dai, Z.; Liu, Y.; Guo, J.; Huang, L.; Zhang, X. Yeast synthetic biology for high-value metabolites. FEMS Yeast Res. 2015, 15, 1-11. [CrossRef] [PubMed]

19. Li, M.; Borodina, I. Application of synthetic biology for production of chemicals in yeast Saccharomyces cerevisiae. FEMS Yeast Res 2015, 15. [CrossRef]

20. Broach, J.R. Nutritional control of growth and development in yeast. Genet. 2012, 192, 73-105. [CrossRef] [PubMed]

21. Santangelo, G.M. Glucose signaling in Saccharomyces cerevisiae. Microbiol. Mol. Biol. Rev. 2006, 70, $253-282$. [CrossRef] [PubMed]

22. Weinhandl, K.; Winkler, M.; Glieder, A.; Camattari, A. Carbon source dependent promoters in yeasts. Microb. Cell Factor. 2014, 13, 5. [CrossRef] [PubMed]

23. Busti, S.; Coccetti, P.; Alberghina, L.; Vanoni, M. Glucose signaling-mediated coordination of cell growth and cell cycle in Saccharomyces cerevisiae. Sensors 2010, 10, 6195-6240. [CrossRef] [PubMed]

24. Kim, J.-H.; Roy, A.; Jouandot, D.; Cho, K.H. The glucose signaling network in yeast. Biochim. Biophys. Acta-Gen. Subj. 2013, 1830, 5204-5210. [CrossRef] [PubMed]

25. Peeters, K.; Thevelein, J.M. Glucose sensing and signal transduction in Saccharomyces cerevisiae. In Molecular Mechanisms in Yeast Carbon Metab; Springer: Berlin/Heidelberg, German, 2014; pp. 21-56.

26. Tarinejad, A. Glucose Signalling in Saccharomyces cerevisiae. Agric. Commun. 2015, 3, 7-15.

27. Tamanoi, F. Ras signaling in yeast. Genes Cancer 2011, 2, 210-215. [CrossRef] [PubMed]

28. Colombo, S.; Paiardi, C.; Pardons, K.; Winderickx, J.; Martegani, E. Evidence for adenylate cyclase as a scaffold protein for Ras2-Ira interaction in Saccharomyces cerevisie. Cell. Signal. 2014, 26, 1147-1154. [CrossRef] [PubMed]

29. Peeters, T.; Versele, M.; Thevelein, J.M. Directly from G $\alpha$ to protein kinase A: The kelch repeat protein bypass of adenylate cyclase. Trends Biochem. Sci. 2007, 32, 547-554. [CrossRef] [PubMed]

30. Soulard, A.; Cremonesi, A.; Moes, S.; Schütz, F.; Jenö, P.; Hall, M.N. The rapamycin-sensitive phosphoproteome reveals that TOR controls protein kinase A toward some but not all substrates. Mol. Biol. Cell 2010, 21, 3475-3486. [CrossRef] [PubMed]

31. Brown, N.A.; de Gouvea, P.F.; Krohn, N.G.; Savoldi, M.; Goldman, G.H. Functional characterisation of the non-essential protein kinases and phosphatases regulating Aspergillus nidulans hydrolytic enzyme production. Biotechnol. Biofuels 2013, 6, 91. [CrossRef] [PubMed]

32. Ozcan, S.; Johnston, M. Two different repressors collaborate to restrict expression of the yeast glucose transporter genes HXT2 and HXT4 to low levels of glucose. Mol. Cell. Biol. 1996, 16, 5536-5545. [CrossRef] [PubMed] 
33. Palomino, A.; Herrero, P.; Moreno, F. Tpk3 and Snf1 protein kinases regulate Rgt1 association with Saccharomyces cerevisiae HXK2 promoter. Nucleic Acids Res. 2006, 34, 1427-1438. [CrossRef] [PubMed]

34. Ahuatzi, D.; Riera, A.; Peláez, R.; Herrero, P.; Moreno, F. Hxk2 regulates the phosphorylation state of Mig1 and therefore its nucleocytoplasmic distribution. J. Biol. Chem. 2007, 282, 4485-4493. [CrossRef] [PubMed]

35. Yao, Y.; Tsuchiyama, S.; Yang, C.; Bulteau, A.L.; He, C.; Robison, B.; Tsuchiya, M.; Miller, D.; Briones, V.; Tar, K. Proteasomes, Sir2, and Hxk2 form an interconnected aging network that impinges on the AMPK/Snf1-regulated transcriptional repressor Mig1. PLoS Genet. 2015, 11, e1004968. [CrossRef] [PubMed]

36. Kim, J.-H.; Johnston, M. Two glucose-sensing pathways converge on Rgt1 to regulate expression of glucose transporter genes in Saccharomyces cerevisiae. J. Biol. Chem. 2006, 281, 26144-26149. [CrossRef] [PubMed]

37. Roy, A.; Kim, J.-H. Endocytosis and vacuolar degradation of the yeast cell surface glucose sensors Rgt2 and Snf3. J. Biol. Chem. 2016, 291, 14913. [CrossRef] [PubMed]

38. Vega, M.; Riera, A.; Fernández-Cid, A.; Herrero, P.; Moreno, F. Hexokinase 2 is an intracellular glucose sensor of yeast cells that maintains the structure and activity of Mig1 protein repressor complex. J. Biol. Chem. 2016, 291, 7267-7285. [CrossRef] [PubMed]

39. Rolland, F.; Winderickx, J.; Thevelein, J.M. Glucose-sensing and-signalling mechanisms in yeast. FEMS Yeast Res. 2002, 2, 183-201. [CrossRef] [PubMed]

40. Welkenhuysen, N.; Borgqvist, J.; Backman, M.; Bendrioua, L.; Goksör, M.; Adiels, C.B.; Cvijovic, M.; Hohmann, S. Single-cell study links metabolism with nutrient signaling and reveals sources of variability. BMC Syst. Biol. 2017, 11, 59. [CrossRef] [PubMed]

41. Otterstedt, K.; Larsson, C.; Bill, R.M.; Ståhlberg, A.; Boles, E.; Hohmann, S.; Gustafsson, L. Switching the mode of metabolism in the yeast Saccharomyces cerevisiae. EMBO Rep. 2004, 5, 532-537. [CrossRef] [PubMed]

42. Tabba, S.; Mangat, S.; McCartney, R.; Schmidt, M.C. PP1 phosphatase-binding motif in Reg1 protein of Saccharomyces cerevisiae is required for interaction with both the PP1 phosphatase Glc7 and the Snf1 protein kinase. Cell. Signal. 2010, 22, 1013-1021. [CrossRef] [PubMed]

43. Ruiz, A.; Xu, X.; Carlson, M. Roles of two protein phosphatases, Reg1-Glc7 and Sit4, and glycogen synthesis in regulation of SNF1 protein kinase. Proc. Natl. Acad. Sci. USA 2011, 108, 6349-6354. [CrossRef] [PubMed]

44. Mayer, F.V.; Heath, R.; Underwood, E.; Sanders, M.J.; Carmena, D.; McCartney, R.R.; Leiper, F.C.; Xiao, B.; Jing, C.; Walker, P.A. ADP regulates SNF1, the Saccharomyces cerevisiae homolog of AMP-activated protein kinase. Cell Metab. 2011, 14, 707-714. [CrossRef] [PubMed]

45. Vincent, O.; Kuchin, S.; Hong, S.-P.; Townley, R.; Vyas, V.K.; Carlson, M. Interaction of the Srb10 kinase with Sip4, a transcriptional activator of gluconeogenic genes in Saccharomyces cerevisiae. Mol. Cell. Biol. 2001, 21, 5790-5796. [CrossRef] [PubMed]

46. Ahuatzi, D.; Herrero, P.; De, L.C.T.; Moreno, F. The glucose-regulated nuclear localization of hexokinase 2 in Saccharomyces cerevisiae is Mig1-dependent. J. Biol. Chem. 2004, 279, 14440-14446. [CrossRef] [PubMed]

47. Papamichos-Chronakis, M.; Petrakis, T.; Ktistaki, E.; Topalidou, I.; Tzamarias, D. Cti6, a PHD domain protein, bridges the Cyc8-Tup1 corepressor and the SAGA coactivator to overcome repression at GAL1. Mol. Cell 2002, 9, 1297-1305. [CrossRef]

48. Papamichos-Chronakis, M.; Gligoris, T.; Tzamarias, D. The Snf1 kinase controls glucose repression in yeast by modulating interactions between the Mig1 repressor and the Cyc8-Tup1 co-repressor. EMBO Rep. 2004, 5, 368-372. [CrossRef] [PubMed]

49. Madi, L.; McBride, S.A.; Bailey, L.A.; Ebbole, D.J. rco-3, a gene involved in glucose transport and conidiation in Neurospora crassa. Genetics 1997, 146, 499-508. [PubMed]

50. Flipphi, M.; van de Vondervoort, P.J.; Ruijter, G.J.; Visser, J.; Arst, H.N.; Felenbok, B. Onset of Carbon Catabolite Repression in Aspergillus nidulans. Parallel involvement of hexokinase and GLUCOKINASE in sugar signaling. J. Biol. Chem. 2003, 278, 11849-11857. [CrossRef] [PubMed]

51. Bernardo, S.M.; Gray, K.-A.; Todd, R.B.; Cheetham, B.F.; Katz, M.E. Characterization of regulatory non-catalytic hexokinases in Aspergillus nidulans. Mol. Genet. Genom. 2007, 277, 519-532. [CrossRef] [PubMed]

52. Doehlemann, G.; Berndt, P.; Hahn, M. Different signalling pathways involving a G $\alpha$ protein, cAMP and a MAP kinase control germination of Botrytis cinerea conidia. Mol. Microbiol. 2006, 59, 821-835. [CrossRef] [PubMed] 
53. Lafon, A.; Seo, J.-A.; Han, K.-H.; Yu, J.-H.; d’Enfert, C. The heterotrimeric G-protein GanB ( $\alpha)$-SfaD ( $\beta)-G p g A$ $(\gamma)$ is a carbon source sensor involved in early cAMP-dependent germination in Aspergillus nidulans. Genetics 2005, 171, 71-80. [CrossRef] [PubMed]

54. Zuber, S.; Hynes, M.J.; Andrianopoulos, A. The G-protein $\alpha$-subunit GasC plays a major role in germination in the dimorphic fungus Penicillium marneffei. Genetics 2003, 164, 487-499. [PubMed]

55. Xue, C.; Bahn, Y.-S.; Cox, G.M.; Heitman, J. G protein-coupled receptor Gpr4 senses amino acids and activates the cAMP-PKA pathway in Cryptococcus neoformans. Mol. Biol. Cell 2006, 17, 667-679. [CrossRef] [PubMed]

56. Alspaugh, J.A.; Perfect, J.R.; Heitman, J. Cryptococcus neoformans mating and virulence are regulated by the G-protein $\alpha$ subunit GPA1 and cAMP. Genes Dev. 1997, 11, 3206-3217. [CrossRef] [PubMed]

57. Affeldt, K.J.; Brodhagen, M.; Keller, N.P. Aspergillus oxylipin signaling and quorum sensing pathways depend on $G$ protein-coupled receptors. Toxins 2012, 4, 695-717. [CrossRef] [PubMed]

58. Föge, M.; Heinekamp, T.; Brakhage, A. G protein-coupled receptors of the human-pathogenic fungus Aspergillus fumigatus. Mycoses 2012, 55, 141.

59. Brown, N.A.; Dos Reis, T.F.; Ries, L.N.A.; Caldana, C.; Mah, J.H.; Yu, J.H.; Macdonald, J.M.; Goldman, G.H. G-protein coupled receptor-mediated nutrient sensing and developmental control in Aspergillus nidulans. Mol. Microbiol. 2015, 98, 420-439. [CrossRef] [PubMed]

60. Li, L.; Borkovich, K.A. GPR-4 is a predicted G-protein-coupled receptor required for carbon source-dependent asexual growth and development in Neurospora crassa. Eukaryot. Cell 2006, 5, 1287-1300. [CrossRef] [PubMed]

61. Li, L.; Wright, S.J.; Krystofova, S.; Park, G.; Borkovich, K.A. Heterotrimeric G protein signaling in filamentous fungi. Annu. Rev. Microbiol. 2007, 61, 423-452. [CrossRef] [PubMed]

62. De Souza, W.R.; Morais, E.R.; Krohn, N.G.; Savoldi, M.; Goldman, M.H.S.; Rodrigues, F.; Caldana, C.; Semelka, C.T.; Tikunov, A.P.; Macdonald, J.M. Identification of metabolic pathways influenced by the G-protein coupled receptors GprB and GprD in Aspergillus nidulans. PLoS ONE 2013, 8, e62088. [CrossRef] [PubMed]

63. Krijgsheld, P.; Bleichrodt, R.; Van Veluw, G.; Wang, F.; Müller, W.; Dijksterhuis, J.; Wösten, H. Development in Aspergillus. Stud. Mycol. 2013, 74, 1-29. [CrossRef] [PubMed]

64. Fuller, K.K.; Rhodes, J.C. Protein kinase A and fungal virulence: A sinister side to a conserved nutrient sensing pathway. Virulence 2012, 3, 109-121. [CrossRef] [PubMed]

65. Fuller, K.K.; Richie, D.L.; Feng, X.; Krishnan, K.; Stephens, T.J.; Wikenheiser-Brokamp, K.A.; Askew, D.S.; Rhodes, J.C. Divergent Protein Kinase A isoforms co-ordinately regulate conidial germination, carbohydrate metabolism and virulence in Aspergillus fumigatus. Mol. Microbiol. 2011, 79, 1045-1062. [CrossRef] [PubMed]

66. Roy, P.; Lockington, R.A.; Kelly, J.M. CreA-mediated repression in Aspergillus nidulans does not require transcriptional auto-regulation, regulated intracellular localisation or degradation of CreA. Fungal Genet. Biol. 2008, 45, 657-670. [CrossRef] [PubMed]

67. Fleck, C.B.; Brock, M. Aspergillus fumigatus catalytic glucokinase and hexokinase: Expression analysis and importance for germination, growth, and conidiation. Eukaryot. Cell 2010, 9, 1120-1135. [CrossRef] [PubMed]

68. Madi, L.; Ebbole, D.J.; White, B.T.; Yanofsky, C. Mutants of Neurospora crassa that alter gene expression and conidia development. Proc. Natl. Acad. Sci. USA 1994, 91, 6226-6230. [CrossRef] [PubMed]

69. Jørgensen, H.; Kristensen, J.B.; Felby, C. Enzymatic conversion of lignocellulose into fermentable sugars: Challenges and opportunities. Biofuels Bioprod. Biorefin. 2007, 1, 119-134. [CrossRef]

70. Brown, N.A.; Ries, L.N.A.; Goldman, G.H. How nutritional status signalling coordinates metabolism and lignocellulolytic enzyme secretion. Fungal Genet. Biol. 2014, 72, 48-63. [CrossRef] [PubMed]

71. Ubersax, J.A.; Ferrell, J.E., Jr. Mechanisms of specificity in protein phosphorylation. Nat. Rev. Mol. Cell Biol. 2007, 8, 530-541. [CrossRef] [PubMed]

72. Assis, L.J.; Ries, L.N.A.; Savoldi, M.; Reis, T.F.; Brown, N.A.; Goldman, G.H. Aspergillus nidulans protein kinase A plays an important role in cellulase production. Biotechnol. Biofuels 2015, 8, 213. [CrossRef] [PubMed]

73. Alam, M.A.; Kamlangdee, N.; Kelly, J.M. The CreB deubiquitinating enzyme does not directly target the CreA repressor protein in Aspergillus nidulans. Curr. Genet. 2017, 63, 647-667. [CrossRef] [PubMed]

74. García, I.; Mathieu, M.; Nikolaev, I.; Felenbok, B.; Scazzocchio, C. Roles of the Aspergillus nidulans homologues of Tup1 and Ssn6 in chromatin structure and cell viability. FEMS Microbiol. Lett. 2008, 289, 146-154. [CrossRef] [PubMed] 
75. Hicks, J.; Lockington, R.A.; Strauss, J.; Dieringer, D.; Kubicek, C.P.; Kelly, J.; Keller, N. RcoA has pleiotropic effects on Aspergillus nidulans cellular development. Mol. Microbiol. 2001, 39, 1482-1493. [CrossRef] [PubMed]

76. Yamashiro, C.T.; Ebbole, D.J.; Lee, B.-U.; Brown, R.E.; Bourland, C.; Madi, L.; Yanofsky, C. Characterization of rco-1 of Neurospora crassa, a pleiotropic gene affecting growth and development that encodes a homolog of Tup1 of Saccharomyces cerevisiae. Mol. Cell. Biol. 1996, 16, 6218-6228. [CrossRef] [PubMed]

77. Lee, K.; Ebbole, D.J. Tissue-Specific Repression of Starvation and Stress Responses of the Neurospora crassa con-10Gene Is Mediated by RCO1. Fungal Genet. Biol. 1998, 23, 269-278. [CrossRef] [PubMed]

78. Lockington, R.A.; Kelly, J.M. Carbon catabolite repression in Aspergillus nidulans involves deubiquitination. Mol. Microbiol. 2001, 40, 1311-1321. [CrossRef] [PubMed]

79. Lockington, R.A.; Kelly, J.M. The WD40-repeat protein CreC interacts with and stabilizes the deubiquitinating enzyme CreB in vivo in Aspergillus nidulans. Mol. Microbiol. 2002, 43, 1173-1182. [CrossRef] [PubMed]

80. Cupertino, F.B.; Virgilio, S.; Freitas, F.Z.; de Souza Candido, T.; Bertolini, M.C. Regulation of glycogen metabolism by the CRE-1, RCO-1 and RCM-1 proteins in Neurospora crassa. The role of CRE-1 as the central transcriptional regulator. Fungal Genet. Biol. 2015, 77, 82-94. [CrossRef] [PubMed]

81. Alam, M.A.; Kelly, J.M. Proteins interacting with CreA and CreB in the carbon catabolite repression network in Aspergillus nidulans. Curr. Genet. 2017, 63, 669-683. [CrossRef] [PubMed]

82. Khosravi, C.; Benocci, T.; Battaglia, E.; Benoit, I.; de Vries, R.P. Chapter one-sugar catabolism in Aspergillus and other fungi related to the utilization of plant biomass. Adv. Appl. Microbiol. 2015, 90, 1-28. [PubMed]

83. Ebbole, D.J. Carbon catabolite repression of gene expression and conidiation in Neurospora crassa. Fungal Genet. Biol. 1998, 25, 15-21. [CrossRef] [PubMed]

84. Tudzynski, B.; Liu, S.; Kelly, J.M. Carbon catabolite repression in plant pathogenic fungi: Isolation and characterization of the Gibberella fujikuroi and Botrytis cinerea creA genes. FEMS Microbiol. Lett. 2000, 184, 9-15. [CrossRef] [PubMed]

85. Tonukari, N.J.; Scott-Craig, J.S.; Walton, J.D. Isolation of the carbon catabolite repressor (CREA) gene from the plant-pathogenic fungus Cochliobolus carbonum. DNA Seq. 2003, 14, 103-107. [CrossRef] [PubMed]

86. Benocci, T.; Aguilar-Pontes, M.V.; Zhou, M.; Seiboth, B.; Vries, R.P. Regulators of plant biomass degradation in ascomycetous fungi. Biotechnol. Biofuels 2017, 10, 152. [CrossRef] [PubMed]

87. Suzuki, M.; Hikita, M. Anomalous Field-Induced Resistive Transition in La2-xSrxCuO4. Jpn. J. Appl. Phys. 1989, 28, L1368. [CrossRef]

88. David, H.; Krogh, A.M.; Roca, C.; Åkesson, M.; Nielsen, J. CreA influences the metabolic fluxes of Aspergillus nidulans during growth on glucose and xylose. Microbiology 2005, 151, 2209-2221. [CrossRef] [PubMed]

89. Klaubauf, S.; Narang, H.M.; Post, H.; Zhou, M.; Brunner, K.; Mach-Aigner, A.R.; Mach, R.L.; Heck, A.J.; Altelaar, A.M.; de Vries, R.P. Similar is not the same: Differences in the function of the (hemi-) cellulolytic regulator XlnR (Xlr1/Xyr1) in filamentous fungi. Fungal Genet. Biol. 2014, 72, 73-81. [CrossRef] [PubMed]

90. Ruijter, G.J.; Visser, J. Carbon repression in Aspergilli. FEMS Microbiol. Lett. 1997, 151, 103-114. [CrossRef] [PubMed]

91. Macios, M.; Caddick, M.X.; Weglenski, P.; Scazzocchio, C.; Dzikowska, A. The GATA factors AREA and AREB together with the co-repressor NMRA, negatively regulate arginine catabolism in Aspergillus nidulans in response to nitrogen and carbon source. Fungal Genet. Biol. 2012, 49, 189-198. [CrossRef] [PubMed]

92. Wong, K.H.; Hynes, M.J.; Todd, R.B.; Davis, M.A. Deletion and overexpression of the Aspergillus nidulans GATA factor AreB reveals unexpected pleiotropy. Microbiology 2009, 155, 3868-3880. [CrossRef] [PubMed]

93. Delmas, S.; Pullan, S.T.; Gaddipati, S.; Kokolski, M.; Malla, S.; Blythe, M.J.; Ibbett, R.; Campbell, M.; Liddell, S. Uncovering the genome-wide transcriptional responses of the filamentous fungus Aspergillus niger to lignocellulose using RNA sequencing. PLoS Genet. 2012, 8, e1002875. [CrossRef] [PubMed]

94. Znameroski, E.A.; Coradetti, S.T.; Roche, C.M.; Tsai, J.C.; Iavarone, A.T.; Cate, J.H.; Cate, J.H.; Glass, N.L. Induction of lignocellulose-degrading enzymes in Neurospora crassa by cellodextrins. Proc. Natl. Acad. Sci. USA 2012, 109, 6012-6017. [CrossRef] [PubMed]

95. Cziferszky, A.; Mach, R.L.; Kubicek, C.P. Phosphorylation positively regulates DNA binding of the carbon catabolite repressor Cre1 of Hypocrea jecorina (Trichoderma reesei). J. Biol. Chem. 2002, 277, 14688-14694. [CrossRef] [PubMed]

96. Cziferszky, A.; Seiboth, B.; Kubicek, C.P. The Snf1 kinase of the filamentous fungus Hypocrea jecorina phosphorylates regulation-relevant serine residues in the yeast carbon catabolite repressor Mig1 but not in the filamentous fungal counterpart Cre1. Fungal Genet. Biol. 2003, 40, 166-175. [CrossRef] 
97. Mathieu, M.; Fillinger, S.; Felenbok, B. In Vivo studies of upstream regulatory cis-acting elements of the alcR gene encoding the transactivator of the ethanol regulon in Aspergillus nidulans. Mol. Microbiol. 2000, 36, 123-131. [CrossRef] [PubMed]

98. Mathieu, M.; Nikolaev, I.; Scazzocchio, C.; Felenbok, B. Patterns of nucleosomal organization in the alc regulon of Aspergillus nidulans: Roles of the AlcR transcriptional activator and the CreA global repressor. Mol. Microbiol. 2005, 56, 535-548. [CrossRef] [PubMed]

99. Mach-Aigner, A.R.; Pucher, M.E.; Steiger, M.G.; Bauer, G.E.; Preis, S.J.; Mach, R.L. Transcriptional regulation of xyr1, encoding the main regulator of the xylanolytic and cellulolytic enzyme system in Hypocrea jecorina. Appl. Environ. Microbiol. 2008, 74, 6554-6562. [CrossRef] [PubMed]

100. De Vries, R.; van de Vondervoort, P.; Hendriks, L.; Van de Belt, M.; Visser, J. Regulation of the a-glucuronidase-encoding gene (aguA) from Aspergillus niger. Mol. Genet. Genom. 2002, 268, 96-102. [CrossRef] [PubMed]

101. Sun, J.; Tian, C.; Diamond, S.; Glass, N.L. Deciphering transcriptional regulatory mechanisms associated with hemicellulose degradation in Neurospora crassa. Eukaryot. Cell 2012, 11, 482-493. [CrossRef] [PubMed]

102. Sun, J.; Glass, N.L. Identification of the CRE-1 cellulolytic regulon in Neurospora crassa. PLoS ONE 2011, 6, e25654. [CrossRef] [PubMed]

103. Nitta, M.; Furukawa, T.; Shida, Y.; Mori, K.; Kuhara, S.; Morikawa, Y.; Ogasawara, W. A new Zn (II) 2 Cys 6-type transcription factor BglR regulates $\beta$-glucosidase expression in Trichoderma reesei. Fungal Genet. Biol. 2012, 49, 388-397. [CrossRef] [PubMed]

104. Xiong, Y.; Sun, J.; Glass, N.L. VIB1, a link between glucose signaling and carbon catabolite repression, is essential for plant cell wall degradation by Neurospora crassa. PLoS Genet. 2014, 10, e1004500. [CrossRef] [PubMed]

105. Fujii, T.; Inoue, H.; Ishikawa, K. Decreased cellulase and xylanase production in the fungus Talaromyces cellulolyticus by disruption of tacA and tctA genes, encoding putative zinc finger transcriptional factors. Appl. Biochem. Biotechnol. 2015, 175, 3218-3229. [CrossRef] [PubMed]

106. Coradetti, S.T.; Craig, J.P.; Xiong, Y.; Shock, T.; Tian, C.; Glass, N.L. Conserved and essential transcription factors for cellulase gene expression in ascomycete fungi. Proc. Natl. Acad. Sci. USA 2012, 109, 7397-7402. [CrossRef] [PubMed]

107. Craig, J.P.; Coradetti, S.T.; Starr, T.L.; Glass, N.L. Direct target network of the Neurospora crassa plant cell wall deconstruction regulators CLR-1, CLR-2, and XLR-1. MBio 2015, 6, e01452-15. [CrossRef] [PubMed]

108. Raulo, R.; Kokolski, M.; Archer, D.B. The roles of the zinc finger transcription factors $\mathrm{XlnR}, \mathrm{Clr} A$ and $\mathrm{ClrB}$ in the breakdown of lignocellulose by Aspergillus niger. AMB Exp. 2016, 6, 5. [CrossRef] [PubMed]

109. Aro, N.; Saloheimo, A.; Ilmén, M.; Penttilä, M. ACEII, a novel transcriptional activator involved in regulation of cellulase and xylanase genes of Trichoderma reesei. J. Biol. Chem. 2001, 276, 24309-24314. [CrossRef] [PubMed]

110. Häkkinen, M.; Valkonen, M.J.; Westerholm-Parvinen, A.; Aro, N.; Arvas, M.; Vitikainen, M.; Penttilä, M.; Saloheimo, M.; Pakula, T.M. Screening of candidate regulators for cellulase and hemicellulase production in Trichoderma reesei and identification of a factor essential for cellulase production. Biotechnol. Biofuels 2014, 7, 14. [CrossRef] [PubMed]

111. Yamakawa, Y.; Endo, Y.; Li, N.; Yoshizawa, M.; Aoyama, M.; Watanabe, A.; Kanamaru, K.; Kato, M.; Kobayashi, T. Regulation of cellulolytic genes by McmA, the SRF-MADS box protein in Aspergillus nidulans. Biochem. Biophys. Res. Commun. 2013, 431, 777-782. [CrossRef] [PubMed]

112. Saloheimo, A.; Aro, N.; Ilmén, M.; Penttilä, M. Isolation of the ace1 gene encoding a Cys2-His2 transcription factor involved in regulation of activity of the cellulase promoter cbh1of Trichoderma reesei. J. Biol. Chem. 2000, 275, 5817-5825. [CrossRef] [PubMed]

113. Chilton, I.J.; Delaney, C.; Barham-Morris, J.; Fincham, D.A.; Hooley, P.; Whitehead, M.P. The Aspergillus nidulans stress response transcription factor StzA is ascomycete-specific and shows species-specific polymorphisms in the C-terminal region. Mycol. Res. 2008, 112, 1435-1446. [CrossRef] [PubMed]

114. Schmoll, M.; Tian, C.; Sun, J.; Tisch, D.; Glass, N.L. Unravelling the molecular basis for light modulated cellulase gene expression-the role of photoreceptors in Neurospora crassa. BMC Genom. 2012, 13, 127. [CrossRef] [PubMed]

115. Hurley, J.; Loros, J.J.; Dunlap, J.C. Chapter two-dissecting the mechanisms of the clock in Neurospora. Methods Enzymol. 2015, 551, 29-52. [PubMed] 
116. Dasgupta, A.; Fuller, K.K.; Dunlap, J.C.; Loros, J.J. Seeing the world differently: Variability in the photosensory mechanisms of two model fungi. Environ. Microbiol. 2016, 18, 5-20. [CrossRef] [PubMed]

117. Li, J.; Lin, L.; Li, H.; Tian, C.; Ma, Y. Transcriptional comparison of the filamentous fungus Neurospora crassa growing on three major monosaccharides D-glucose, D-xylose and L-arabinose. Biotechnol. Biofuels 2014, 7, 31. [CrossRef] [PubMed]

118. Battaglia, E.; Visser, L.; Nijssen, A.; van Veluw, G.; Wösten, H.; de Vries, R. Analysis of regulation of pentose utilisation in Aspergillus niger reveals evolutionary adaptations in Eurotiales. Stud. Mycol. 2011, 69, 31-38. [CrossRef] [PubMed]

119. Battaglia, E.; Zhou, M.; de Vries, R.P. The transcriptional activators AraR and XlnR from Aspergillus niger regulate expression of pentose catabolic and pentose phosphate pathway genes. Res. Microbiol. 2014, 165, 531-540. [CrossRef] [PubMed]

120. Klaubauf, S.; Zhou, M.; Lebrun, M.H.; Vries, R.P.; Battaglia, E. A novel l-arabinose-responsive regulator discovered in the rice-blast fungus Pyricularia oryzae (Magnaporthe oryzae). FEBS Lett. 2016, 590, 550-558. [CrossRef] [PubMed]

121. Gomi, K.; Akeno, T.; Minetoki, T.; Ozeki, K.; Kumagai, C.; Okazaki, N.; Iimura, Y. Molecular cloning and characterization of a transcriptional activator gene, amyR, involved in the amylolytic gene expression in Aspergillus oryzae. Biosci. Biotechnol. Biochem. 2000, 64, 816-827. [CrossRef] [PubMed]

122. Benen, J.A.; Wösten, H.A.; Visser, J.; de Vries, R.P. A broader role for AmyR in Aspergillus niger: Regulation of the utilisation of D-glucose or D-galactose containing oligo-and polysaccharides. Appl. Microbiol. Biotechnol. 2012, 93, 285-293.

123. Hasegawa, S.; Takizawa, M.; Suyama, H.; Shintani, T.; Gomi, K. Characterization and expression analysis of a maltose-utilizing (MAL) cluster in Aspergillus oryzae. Fungal Genet. Biol. 2010, 47, 1-9. [CrossRef] [PubMed]

124. Suzuki, K.; Tanaka, M.; Konno, Y.; Ichikawa, T.; Ichinose, S.; Hasegawa-Shiro, S.; Shintani, T.; Gomi, K. Distinct mechanism of activation of two transcription factors, AmyR and MalR, involved in amylolytic enzyme production in Aspergillus oryzae. Appl. Microbiol. Biotechnol. 2015, 99, 1805-1815. [CrossRef] [PubMed]

125. Kunitake, E.; Tani, S.; Sumitani, J.-I.; Kawaguchi, T. A novel transcriptional regulator, ClbR, controls the cellobiose-and cellulose-responsive induction of cellulase and xylanase genes regulated by two distinct signaling pathways in Aspergillus aculeatus. Appl. Microbiol. Biotechnol. 2013, 97, 2017-2028. [CrossRef] [PubMed]

126. Kunitake, E.; Kawamura, A.; Tani, S.; Takenaka, S.; Ogasawara, W.; Sumitani, J.-I.; Kawaguchi, T. Effects of clbR overexpression on enzyme production in Aspergillus aculeatus vary depending on the cellulosic biomass-degrading enzyme species. Biosci. Biotechnol. Biochem. 2015, 79, 488-495. [CrossRef] [PubMed]

127. Li, Y.; Chen, G.; Liu, W. Multiple metabolic signals influence GAL gene activation by modulating the interaction of Gal80p with the transcriptional activator Gal4p. Mol. Microbiol. 2010, 78, 414-428. [CrossRef] [PubMed]

128. Kowalczyk, J.E.; Gruben, B.S.; Battaglia, E.; Wiebenga, A.; Majoor, E.; de Vries, R.P. Genetic Interaction of Aspergillus nidulans galR, $x \operatorname{lnR}$ and araR in regulating D-Galactose and L-Arabinose release and catabolism gene expression. PLoS ONE 2015, 10, e0143200. [CrossRef] [PubMed]

129. Stricker, A.R.; Steiger, M.G.; Mach, R.L. Xyr1 receives the lactose induction signal and regulates lactose metabolism in Hypocrea jecorina. FEBS Lett. 2007, 581, 3915-3920. [CrossRef] [PubMed]

130. Yuan, X.-L.; Roubos, J.A.; van den Hondel, C.A.; Ram, A.F. Identification of InuR, a new Zn (II) 2Cys6 transcriptional activator involved in the regulation of inulinolytic genes in Aspergillus niger. Mol. Genet. Genom. 2008, 279, 11-26. [CrossRef] [PubMed]

131. Zhang, L.; Lubbers, R.J.; Simon, A.; Stassen, J.H.; Vargas Ribera, P.R.; Viaud, M.; van Kan, J.A. A novel Zn2Cys6 transcription factor BcGaaR regulates D-galacturonic acid utilization in Botrytis cinerea. Mol. Microbiol. 2016, 100, 247-262. [CrossRef] [PubMed]

132. Derntl, C.; Rassinger, A.; Srebotnik, E.; Mach, R.L.; Mach-Aigner, A.R. Xpp1 regulates the expression of xylanases, but not of cellulases in Trichoderma reesei. Biotechnol. Biofuels 2015, 8, 112. [CrossRef] [PubMed]

133. Derntl, C.; Kluger, B.; Bueschl, C.; Schuhmacher, R.; Mach, R.L.; Mach-Aigner, A.R. Transcription factor Xpp1 is a switch between primary and secondary fungal metabolism. Proc. Natl. Acad. Sci. USA 2017, 114, E560-E569. [CrossRef] [PubMed] 
134. Mantovani, R. A survey of 178 NF-Y binding CCAAT boxes. Nucleic Acids Res. 1998, 26, 1135-1143. [CrossRef] [PubMed]

135. Zeilinger, S.; Mach, R.L.; Kubicek, C.P. Two adjacent protein binding motifs in the cbh2 (cellobiohydrolase II-encoding) promoter of the fungus Hypocrea jecorina (Trichoderma reesei) cooperate in the induction by cellulose. J. Biol. Chem. 1998, 273, 34463-34471. [CrossRef] [PubMed]

136. Narendja, F.M.; Davis, M.A.; Hynes, M.J. AnCF, the CCAAT Binding Complex of Aspergillus nidulans, Is Essential for the Formation of a DNase I-Hypersensitive Site in the $5^{\prime}$ Region of theamdS Gene. Mol. Cell. Biol. 1999, 19, 6523-6531. [CrossRef] [PubMed]

137. Steidl, S.; Papagiannopoulos, P.; Litzka, O.; Andrianopoulos, A.; Davis, M.A.; Brakhage, A.A.; Hynes, M.J. AnCF, the CCAAT Binding Complex of Aspergillus nidulans, Contains Products of the hapB, hapC, and hapE Genes and Is Required for Activation by the Pathway-Specific Regulatory GeneamdR. Mol. Cell. Biol. 1999, 19, 99-106. [CrossRef] [PubMed]

138. De Vries, R.P.; Jansen, J.; Aguilar, G.; Pařenicová, L.; Joosten, V.; Wülfert, F.; Benen, J.A.; Visser, J. Expression profiling of pectinolytic genes from Aspergillus niger. FEBS Lett. 2002, 530, 41-47. [CrossRef]

139. Gruben, B.S.; Zhou, M.; Wiebenga, A.; Ballering, J.; Overkamp, K.M.; Punt, P.J.; de Vries, R.P. Aspergillus niger RhaR, a regulator involved in L-rhamnose release and catabolism. Appl. Microbiol. Biotechnol. 2014, 98, 5531-5540. [CrossRef] [PubMed]

140. Christensen, U.; Gruben, B.S.; Madrid, S.; Mulder, H.; Nikolaev, I.; de Vries, R.P. Unique regulatory mechanism for D-galactose utilization in Aspergillus nidulans. Appl. Environ. Microbiol. 2011, 77, 7084-7087. [CrossRef] [PubMed]

141. Culleton, H.; McKie, V.; de Vries, R.P. Physiological and molecular aspects of degradation of plant polysaccharides by fungi: What have we learned from Aspergillus? Biotechnol. J. 2013, 8, 884-894. [CrossRef] [PubMed]

142. Todd, R.; Lockington, R.; Kelly, J. The Aspergillus nidulans creC gene involved in carbon catabolite repression encodes a WD40 repeat protein. Mol. Gen. Genet. 2000, 263, 561-570. [CrossRef] [PubMed]

143. Neer, E.J.; Schmidt, C.J.; Nambudripad, R.; Smith, T.F. The ancient regulatory-protein family of WD-repeat proteins. Nature 1994, 371, 297-300. [CrossRef] [PubMed]

144. Denton, J.A.; Kelly, J.M. Disruption of Trichoderma reesei cre2, encoding an ubiquitin C-terminal hydrolase, results in increased cellulase activity. BMC Biotechnol. 2011, 11, 103. [CrossRef] [PubMed]

145. Hynes, M.; Kelly, J.M. Pleiotropic mutants of Aspergillus nidulans altered in carbon metabolism. Mol. Gen. Genet. 1977, 150, 193-204. [CrossRef] [PubMed]

146. Chen, H.I.; Einbond, A.; Kwak, S.-J.; Linn, H.; Koepf, E.; Peterson, S.; Kelly, J.W.; Sudol, M. Characterization of the WW domain of human yes-associated protein and its polyproline-containing ligands. J. Biol. Chem. 1997, 272, 17070-17077. [CrossRef] [PubMed]

147. Kiekhaefer, C.M.; Boyer, M.E.; Johnson, K.D.; Bresnick, E.H. A WW domain-binding motif within the activation domain of the hematopoietic transcription factor NF-E2 is essential for establishment of a tissue-specific histone modification pattern. J. Biol. Chem. 2004, 279, 7456-7461. [CrossRef] [PubMed]

148. Gupta, R.; Kus, B.; Fladd, C.; Wasmuth, J.; Tonikian, R.; Sidhu, S.; Krogan, N.J.; Parkinson, J.; Rotin, D. Ubiquitination screen using protein microarrays for comprehensive identification of Rsp5 substrates in yeast. Mol. Syst. Biol. 2007, 3, 116. [CrossRef] [PubMed]

149. Carlson, M.; Osmond, B.C.; Botstein, D. Mutants of yeast defective in sucrose utilization. Genetics 1981, 98, 25-40. [PubMed]

150. Hardie, D.G. AMP-activated/SNF1 protein kinases: Conserved guardians of cellular energy. Nat. Rev. Mol. Cell Biol. 2007, 8, 774-785. [CrossRef] [PubMed]

151. Hardie, D.G.; Carling, D.; Carlson, M. The AMP-activated/SNF1 protein kinase subfamily: Metabolic sensors of the eukaryotic cell? Annu. Rev. 1998, 67, 821-855. [CrossRef] [PubMed]

152. García-Salcedo, R.; Lubitz, T.; Beltran, G.; Elbing, K.; Tian, Y.; Frey, S.; Wolkenhauer, O.; Krantz, M.; Klipp, E.; Hohmann, S. Glucose de-repression by yeast AMP-activated protein kinase SNF1 is controlled via at least two independent steps. FEBS J. 2014, 281, 1901-1917. [CrossRef] [PubMed]

153. Yi, M.; Park, J.-H.; Ahn, J.-H.; Lee, Y.-H. MoSNF1 regulates sporulation and pathogenicity in the rice blast fungus Magnaporthe oryzae. Fungal Genet. Biol. 2008, 45, 1172-1181. [CrossRef] [PubMed]

154. Brosch, G.; Loidl, P.; Graessle, S. Histone modifications and chromatin dynamics: A focus on filamentous fungi. FEMS Microbiol. Rev. 2008, 32, 409-439. [CrossRef] [PubMed] 
155. Soyer, J.L.; El Ghalid, M.; Glaser, N.; Ollivier, B.; Linglin, J.; Grandaubert, J.; Balesdent, M.H.; Connolly, L.R.; Freitag, M.; Rouxel, T. Epigenetic control of effector gene expression in the plant pathogenic fungus Leptosphaeria maculans. PLoS Genet. 2014, 10, e1004227. [CrossRef] [PubMed]

156. Liu, L.; Jin, G.; Zhou, X. Modeling the relationship of epigenetic modifications to transcription factor binding. Nucleic Acids Res. 2015, 43, 3873-3885. [CrossRef] [PubMed]

157. Bayram, Ö.; Krappmann, S.; Ni, M.; Bok, J.W.; Helmstaedt, K.; Valerius, O.; Braus-Stromeyer, S.; Kwon, N.J.; Keller, N.P.; Yu, J.H. VelB/VeA/LaeA complex coordinates light signal with fungal development and secondary metabolism. Science 2008, 320, 1504-1506. [CrossRef] [PubMed]

158. Karimi-Aghcheh, R.; Bok, J.W.; Phatale, P.A.; Smith, K.M.; Baker, S.E.; Lichius, A.; Omann, M.; Zeilinger, S.; Seiboth, B.; Rhee, C. Functional analyses of Trichoderma reesei LAE1 reveal conserved and contrasting roles of this regulator. G3 Gen. Genomes Genet. 2013, 3, 369-378. [CrossRef] [PubMed]

159. Karimi, A.R.; Németh, Z.; Atanasova, L.; Fekete, E.; Paholcsek, M. The VELVET A Orthologue VEL1 of Trichoderma reesei regulates fungal development and is essential for cellulase gene expression. PLoS ONE 2014, 9, e112799.

160. Fekete, E.; Karaffa, L.; Aghcheh, R.K.; Németh, Z.; Fekete, É.; Orosz, A.; Paholcsek, M.; Stágel, A.; Kubicek, C.P. The transcriptome of lae1 mutants of Trichoderma reesei cultivated at constant growth rates reveals new targets of LAE1 function. BMC Genom. 2014, 15, 447. [CrossRef] [PubMed]

161. Zeilinger, S.; Schmoll, M.; Pail, M.; Mach, R.L.; Kubicek, C.P. Nucleosome transactions on the Hypocrea jecorina (Trichoderma reesei) cellulase promoter cbh2 associated with cellulase induction. Mol. Genet. Genom. 2003, 270, 46-55. [CrossRef] [PubMed]

162. Ronne, H. Glucose repression in fungi. Trends Genet. 1995, 11, 12-17. [CrossRef]

163. García, I.; Gonzalez, R.; Gómez, D.; Scazzocchio, C. Chromatin rearrangements in the prnD-prnB bidirectional promoter: Dependence on transcription factors. Eukaryot. Cell 2004, 3, 144-156. [CrossRef] [PubMed]

164. Ries, L.; Belshaw, N.; Ilmén, M.; Penttilä, M.; Alapuranen, M.; Archer, D. The role of CRE1 in nucleosome positioning within the cbh1 promoter and coding regions of Trichoderma reesei. Appl. Microbiol. Biotechnol. 2014, 98, 749-762. [CrossRef] [PubMed]

165. Mello-de-Sousa, T.M.; Rassinger, A.; Pucher, M.E.; dos Santos Castro, L.; Persinoti, G.F.; Silva-Rocha, R.; Poças-Fonseca, M.J.; Mach, R.L.; Silva, R.N.; Mach-Aigner, A.R. The impact of chromatin remodelling on cellulase expression in Trichoderma reesei. BMC Genom. 2015, 16, 588. [CrossRef] [PubMed]

166. Mello-de-Sousa, T.M.; Rassinger, A.; Derntl, C.; Poças-Fonseca, M.J.; Mach, R.L.; R Mach-Aigner, A. The relation between promoter chromatin status, Xyr1 and cellulase expression in Trichoderma reesei. Curr. Genom. 2016, 17, 145-152. [CrossRef] [PubMed]

167. Xin, Q.; Gong, Y.; Lv, X.; Chen, G.; Liu, W. Trichoderma reesei histone acetyltransferase Gcn5 regulates fungal growth, conidiation, and cellulase gene expression. Curr. Microbiol. 2013, 67, 580-589. [CrossRef] [PubMed]

168. Aro, N.; Pakula, T.; Penttilä, M. Transcriptional regulation of plant cell wall degradation by filamentous fungi. FEMS Microbiol. Rev. 2005, 29, 719-739. [CrossRef] [PubMed]

169. Ilyés, H.; Fekete, E.; Karaffa, L.; Fekete, É.; Sándor, E.; Szentirmai, A.; Kubicek, C.P. CreA-mediated carbon catabolite repression of $\beta$-galactosidase formation in Aspergillus nidulans is growth rate dependent. FEMS Microbiol. Lett. 2004, 235, 147-151. [CrossRef] [PubMed]

170. Mc Mahon, H.; Kelly, C.; Fogarty, W. Effect of growth rate on $\alpha$-amylase production by Streptomyces sp. IMD 2679. Appl. Microbiol. Biotechnol. 1997, 48, 504-509. [CrossRef] [PubMed]

171. Van Hoek, P.; Van Dijken, J.P.; Pronk, J.T. Effect of specific growth rate on fermentative capacity of baker's yeast. Appl. Environ. Microbiol. 1998, 64, 4226-4233. [PubMed]

172. Warner, J.B.; Lolkema, J.S. CcpA-dependent carbon catabolite repression in bacteria. Microbiol. Mol. Biol. Rev. 2003, 67, 475-490. [CrossRef] [PubMed]

173. Strauss, J.; Horvath, H.K.; Abdallah, B.M.; Kindermann, J.; Mach, R.L.; Kubicek, C.P. The function of CreA, the carbon catabolite repressor of Aspergillus nidulans, is regulated at the transcriptional and post-transcriptional level. Mol. Microbiol. 1999, 32, 169-178. [CrossRef] [PubMed]

174. Kuchin, S.; Vyas, V.K.; Carlson, M. Snf1 protein kinase and the repressors Nrg1 and Nrg2 regulate FLO11, haploid invasive growth, and diploid pseudohyphal differentiation. Mol. Cell. Biol. 2002, 22, 3994-4000. [CrossRef] [PubMed] 
175. Somerville, C.; Bauer, S.; Brininstool, G.; Facette, M.; Hamann, T.; Milne, J.; Osborne, E.; Paredez, A.; Persson, S.; Raab, T. Toward a systems approach to understanding plant cell walls. Science 2004, 306, 2206-2211. [CrossRef] [PubMed]

176. Carroll, A.; Somerville, C. Cellulosic biofuels. Annu. Rev. Plant Biol. 2009, 60, 165-182. [CrossRef] [PubMed]

177. Battaglia, E. Regulation and Diversity of Plant Polysaccharide Utilisation in Fungi. Ph.D. Thesis, University Utrecht, Utrecht, The Netherlands, 2011.

178. Kowalczyk, J.E.; Benoit, I.; de Vries, R.P. Regulation of plant biomass utilization in Aspergillus. Adv. Appl. Microbiol. 2014, 88, 31-56. [PubMed]

179. Mäkelä, M.R.; Donofrio, N.; de Vries, R.P. Plant biomass degradation by fungi. Fungal Genet. Biol. 2014, 72, 2-9. [CrossRef] [PubMed]

180. Tonukari, N.J.; Scott-Craig, J.S.; Waltonb, J.D. The Cochliobolus carbonum SNF1 gene is required for cell wall-degrading enzyme expression and virulence on maize. Plant Cell 2000, 12, 237-247. [CrossRef] [PubMed]

181. Ospina-Giraldo, M.D.; Mullins, E.; Kang, S. Loss of function of the Fusarium oxysporum SNF1 gene reduces virulence on cabbage and Arabidopsis. Curr. Genet. 2003, 44, 49-57. [CrossRef] [PubMed]

182. Hedbacker, K.; Carlson, M. SNF1/AMPK pathways in yeast. Front. Biosci. A J. Virtual Libr. 2008, $13,2408$. [CrossRef]

183. Orejas, M.; MacCabe, A.P.; Pérez González, J.A.; Kumar, S.; Ramón, D. Carbon catabolite repression of the Aspergillus nidulans xlnA gene. Mol. Microbiol. 1999, 31, 177-184. [CrossRef] [PubMed]

184. Jonkers, W.; Rep, M. Mutation of CRE1 in Fusarium oxysporum reverts the pathogenicity defects of the FRP1 deletion mutant. Mol. Microbiol. 2009, 74, 1100-1113. [CrossRef] [PubMed]

185. Mach-Aigner, A.R.; Omony, J.; Jovanovic, B.; van Boxtel, A.J.; de Graaff, L.H. D-Xylose concentrationdependent hydrolase expression profiles and the function of $\mathrm{CreA}$ and $\mathrm{X} \ln \mathrm{R}$ in Aspergillus niger. Appl. Environ. Microbiol. 2012, 78, 3145-3155. [CrossRef] [PubMed]

186. Felenbok, B.; Flipphi, M.; Nikolaev, I. Ethanol catabolism in Aspergillus nidulans: A model system for studying gene regulation. Prog.Nucleic Acid Res. Mol. Biol. 2001, 69, 149-204. [PubMed]

187. Fillinger, S.; Felenbok, B. A newly identified gene cluster in Aspergillus nidulans comprises five novel genes localized in the alc region that are controlled both by the specific transactivator AlcR and the general carbon-catabolite repressor CreA. Mol. Microbiol. 1996, 20, 475-488. [CrossRef] [PubMed]

188. Flipphi, M.; Mathieu, M.; Cirpus, I.; Panozzo, C.; Felenbok, B. Regulation of the aldehyde dehydrogenase gene (aldA) and its role in the control of the coinducer level necessary for induction of the ethanol utilization pathway in Aspergillus nidulans. J. Biol. Chem. 2001, 276, 6950-6958. [CrossRef] [PubMed]

189. Flipphi, M.; Kocialkowska, J.; Felenbok, B. Characteristics of physiological inducers of the ethanol utilization (alc) pathway in Aspergillus nidulans. Biochem. J. 2002, 364, 25-31. [CrossRef] [PubMed]

190. Mathieu, M.; Felenbok, B. The Aspergillus nidulans CREA protein mediates glucose repression of the ethanol regulon at various levels through competition with the ALCR-specific transactivator. EMBO J. 1994, 13, 4022. [PubMed]

191. Panozzo, C.; Cornillot, E.; Felenbok, B. The CreA Repressor Is the Sole DNA-binding Protein Responsible for Carbon Catabolite Repression of the alcA Gene in Aspergillus nidulans via Its Binding to a Couple of Specific Sites. J. Biol. Chem. 1998, 273, 6367-6372. [CrossRef] [PubMed]

192. Takashima, S.; Iikura, H.; Nakamura, A.; Masaki, H.; Uozumi, T. Analysis of Cre1 binding sites in the Trichoderma reesei cbh1 upstream region. FEMS Microbiol. Lett. 1996, 145, 361-366. [CrossRef] [PubMed]

193. Portnoy, T.; Margeot, A.; Seidl-Seiboth, V.; Le Crom, S.; Chaabane, F.B.; Linke, R.; Seiboth, B.; Kubicek, C.P. Differential regulation of the cellulase transcription factors XYR1, ACE2, and ACE1 in Trichoderma reesei strains producing high and low levels of cellulase. Eukaryot. Cell 2011, 10, 262-271. [CrossRef] [PubMed]

194. Antoniêto, A.C.C.; dos Santos Castro, L.; Silva-Rocha, R.; Persinoti, G.F.; Silva, R.N. Defining the genome-wide role of CRE1 during carbon catabolite repression in Trichoderma reesei using RNA-Seq analysis. Fungal Genet. Biol. 2014, 73, 93-103. [CrossRef] [PubMed]

195. Lorito, M.; Mach, R.L.; Sposato, P.; Strauss, J.; Peterbauer, C.K.; Kubicek, C.P. Mycoparasitic interaction relieves binding of the Cre1 carbon catabolite repressor protein to promoter sequences of the ech42 (endochitinase-encoding) gene in Trichoderma harzianum. Proc. Natl. Acad. Sci. USA 1996, 93, 14868-14872. [CrossRef] [PubMed] 
196. Fang, W.; Pava-Ripoll, M.; Wang, S.; Leger, R.S. Protein kinase A regulates production of virulence determinants by the entomopathogenic fungus, Metarhizium anisopliae. Fungal Genet. Biol. 2009, 46, 277-285. [CrossRef] [PubMed]

197. Fang, W.; Leng, B.; Xiao, Y.; Jin, K.; Ma, J.; Fan, Y.; Feng, J.; Yang, X.; Zhang, Y.; Pei, Y. Cloning of Beauveria bassiana chitinase gene Bbchit1 and its application to improve fungal strain virulence. Appl. Environ. Microbiol. 2005, 71, 363-370. [CrossRef] [PubMed]

198. Screen, S.; Bailey, A.; Charnley, K.; Cooper, R.; Clarkson, J. Carbon regulation of the cuticle-degrading enzyme PR1 from Metarhizium anisopliae may involve a trans-acting DNA-binding protein CRR1, a functional equivalent of the Aspergillus nidulans CREA protein. Curr. Genet. 1997, 31, 511-518. [CrossRef] [PubMed]

199. Mondal, S.; Baksi, S.; Koris, A.; Vatai, G. Journey of enzymes in entomopathogenic fungi. Pac. Sci. Rev. A Nat. Sci. Eng. 2016, 18, 85-99. [CrossRef]

200. Jin, K.; Luo, Z.; Jiang, X.; Zhang, Y.; Zhou, Y.; Pei, Y. Carbon catabolite repressor gene BbCre1 influences carbon source uptake but does not have a big impact on virulence in Beauveria bassiana. J. Invertebr. Pathol. 2011, 106, 400-406. [CrossRef] [PubMed]

201. Wilson, R.A.; Gibson, R.P.; Quispe, C.F.; Littlechild, J.A.; Talbot, N.J. An NADPH-dependent genetic switch regulates plant infection by the rice blast fungus. Proc. Natl. Acad. Sci. USA 2010, 107, 21902-21907. [CrossRef] [PubMed]

202. Fernandez, J.; Wright, J.D.; Hartline, D.; Quispe, C.F.; Madayiputhiya, N.; Wilson, R.A. Principles of carbon catabolite repression in the rice blast fungus: Tps1, Nmr1-3, and a MATE-Family Pump regulate glucose metabolism during Infection. PLoS Genet. 2012, 8, e1002673. [CrossRef] [PubMed]

203. Cho, Y.; Kim, K.H.; La Rota, M.; Scott, D.; Santopietro, G.; Callihan, M.; Mitchell, T.K.; Lawrence, C.B. Identification of novel virulence factors associated with signal transduction pathways in Alternaria brassicicola. Mol. Microbiol. 2009, 72, 1316-1333. [CrossRef] [PubMed]

204. Tzima, A.K.; Paplomatas, E.J.; Rauyaree, P.; Ospina-Giraldo, M.D.; Kang, S. VdSNF1, the sucrose nonfermenting protein kinase gene of Verticillium dahliae, is required for virulence and expression of genes involved in cell-wall degradation. Mol. Plant-Microbe Interact. 2011, 24, 129-142. [CrossRef] [PubMed]

205. Nakari-Setälä, T.; Paloheimo, M.; Kallio, J.; Vehmaanperä, J.; Penttilä, M.; Saloheimo, M. Genetic modification of carbon catabolite repression in Trichoderma reesei for improved protein production. Appl. Environ. Microbiol. 2009, 75, 4853-4860. [CrossRef] [PubMed]

206. Fujii, T.; Inoue, H.; Ishikawa, K. Enhancing cellulase and hemicellulase production by genetic modification of the carbon catabolite repressor gene, creA, in Acremonium cellulolyticus. AMB Exp. 2013, 3, 73. [CrossRef] [PubMed]

207. Bi, F.; Barad, S.; Ment, D.; Luria, N.; Dubey, A.; Casado, V.; Glam, N.; Mínguez, J.D.; Espeso, E.A.; Fluhr, R. Carbon regulation of environmental $\mathrm{pH}$ by secreted small molecules that modulate pathogenicity in phytopathogenic fungi. Mol. Plant Pathol. 2016, 17, 1178-1195. [CrossRef] [PubMed]

208. Beattie, S.R.; Mark, K.M.; Thammahong, A.; Ries, L.N.A.; Dhingra, S.; Caffrey-Carr, A.K.; Cheng, C.; Black, C.C.; Bowyer, P.; Bromley, M.J. Filamentous fungal carbon catabolite repression supports metabolic plasticity and stress responses essential for disease progression. PLoS Pathog. 2017, 13, e1006340. [CrossRef] [PubMed]

209. Vinuselvi, P.; Kim, M.-K.; Lee, S.-K.; Ghim, C.-M. Rewiring carbon catabolite repression for microbial cell factory. BMB Rep. 2012, 45, 59-70. [CrossRef] [PubMed]

(C) 2017 by the authors. Licensee MDPI, Basel, Switzerland. This article is an open access article distributed under the terms and conditions of the Creative Commons Attribution (CC BY) license (http://creativecommons.org/licenses/by/4.0/). 